\title{
PROTECTIVE ROLE OF DIETARY VITAMIN E AGAINST OXIDATIVE STRESS INDUCED BY COPPER SULPHATE IN NILE TILAPIA (OREOCHROMIS NILOTICUS)
}

\author{
HEBA A. TOLBA ${ }^{1}$; EMAN I.M. ISMAIL ${ }^{2}$; SALWA A.M. EID ${ }^{3}$; \\ MERVAT A. AYOUB ${ }^{4}$ and ENAS A. ABBAS ${ }^{5}$ \\ ${ }^{1}$ Department of Fish Health and Management, Central Laboratory for Aquaculture Research, Abo-Hammad, Egypt, \\ (CLAR), Agriculture Research Center (ARC), Egypt. \\ ${ }^{2}$ Department of Biochemistry, Zagazig Provincial Laboratory, Animal Health Research Institute (AHRI), Agriculture \\ Research Center (ARC), Egypt. \\ ${ }^{3}$ Department of Pathology, Clinical Pathology, Zagazig Provincial Laboratory, Animal Health Research Institute (AHRI), \\ Agriculture Research Center (ARC), Egypt \\ 4 Department of Pathology, Histopathology, Zagazig Provincial Laboratory, Animal Health Research Institute (AHRI), \\ Agriculture Research Center (ARC), Egypt. \\ ${ }^{5}$ Department of Biochemistry, Toxicology Unit, Animal Health Research Institute (AHRI), Agriculture Research Center \\ (ARC), Egypt
}

Received: 27 Sebtember 2020; Accepted: 30 October 2020

\begin{abstract}
120 Nile tilapia were divided into four groups, the first group (G1) was fed on a commercial diet (control group), the second group (G2) was fed on commercial diets supplemented with vitamin E (Vit E, $600 \mathrm{mg} / \mathrm{kg}$ diet), the third group (G3) was fed on commercial diet and exposed to Copper sulfate pentahydrate $(\mathrm{CuSO} 4.5 \mathrm{H} 2 \mathrm{O})$ at a dose of $0.32 \mathrm{of} \mathrm{mg/L}$. The fourth group (G4) was fed on a diet supplemented with Vit E $(600 \mathrm{mg} / \mathrm{kg}$ diet $)$ and exposed to $0.32 \mathrm{of} \mathrm{CuSO} 4 \mathrm{mg} / \mathrm{L}$. At the end of the feeding trial, fish were challenged by intraperitoneal injection of $0.1 \mathrm{ml}$ dose of virulent Aeromonas hydrophila $\left(5 \times 10^{5} \mathrm{CFU} /\right.$ fish). Blood samples and tissue samples were collected after (10, 20 and 30 days) of treatment and a week post-challenge. Fish exposed to CuSO4 exhibited a significant decrease in the weight gain, relative body weight gain and feed efficiency ratio, while significantly increased in fish exposed to $\mathrm{CuSO} 4$ and given Vit E. Furthermore, cumulative mortality was high in challenged fish exposed to CuSO4. Fish exposed to $\mathrm{CuSO} 4$ exhibited a significant decline in red blood cell count, hemoglobin concentration, packed cell volume and serum immunoglobulin $\mathrm{M}$ pre and post-challenge throughout the experiment. However, white blood corpuscles count, lymphocytes and neutrophils count increased in fish exposed to CuSO4 pre and post-challenge. CuSO4 exposure induced a significant increase in serum alanine aminotransferase, aspartate aminotransferase, creatinine and hepatic antioxidants; superoxide dismutase and catalase levels pre and post- challenge of Nile tilapia throughout the experiment, while glutathione level was significantly decreased. CuSO4 exposure induced degenerative changes in the liver, while the kidneys revealed highly dilated capillaries and degenerated renal tubules and round cell aggregations in the gill arches beside marked mucinous degeneration in the gill filaments were seen. The obtained findings also revealed the protective effect of Vit. E against copper sulfate toxicity and fish susceptibility to Aeromonas hydrophila challenge through enhanced growth performance, immune response, hemato-biochemical parameters and increased antioxidants activities. The lowest mortality and pathological lesions were recorded in fish treated with Vit. E.
\end{abstract}

Keywords: Nile tilapia, Copper Sulphate, Vitamin E, Aeromonas hydrophila, Toxicology, Histopathology.

Corresponding author: ENAS A. ABBAS

E-mail address: abbasenas@gmail.com

Present address: Department of Biochemistry, Toxicology Unit, Animal Health Research Institute (AHRI), Agriculture Research Center (ARC), Egyp 


\section{INTRODUCTION}

Oreochromis niloticus commonly used as a biomonitor of water pollution due to its metal tolerance and availability in many polluted sites (Kwok et al., 2010). Environmental contamination of heavy metals in freshwater ecosystems is due to their bioaccumulation and potential toxicity (Wang et al., 2014). Copper sulfate is used worldwide as an algaecide and a fungicide in aquaculture and agriculture. Moreover, in the aquaculture industry, copper sulfate is used as a therapeutic chemical for various ectoparasitic and bacterial challenges (Lasiene et al., 2016). The recommended $\mathrm{Cu}$ concentrations for fish therapeutic and control of algae and vascular plants in aquaria and fish ponds purposes usually range from 0.05 to 1.0 $\mathrm{mg} / \mathrm{L}$ (Mal et al., 2002). The analysis of hematological and biochemical parameters in fish can contribute to the assessment of the animal's health and also the habitat conditions (Thrall, 2004). Elevated aquatic copper levels cause a range of negative effects on fish such as reduced growth, interference with whole-body ion-regulation (Schjolden et al., 2007). Elevated aquatic copper concentrations induced the overproduction of reactive oxygen species (ROS), which cause oxidative damage to several fish species (Lushchak, 2011). The gill is the main place for copper uptake, and because it has constant and direct contact with the external environment (Atabati et al., 2015). When present at high concentrations, copper may cause severe histopathological changes in the gills of teleost fish (Jooyandeh et al., 2016). Copper poisoning can cause pathological changes in various tissues such as the liver (Nawaz et al., 2005) and kidneys (Jiraungkoorskul et al., 2007). The lack of disease control has the potential of being the limiting factor of fish production. Improving disease resistance of cultured fish are major challenges facing fish culturists, especially A. hydrophila bacterial challenge that causes mass mortalities (Rakus et al., 2008).

Dietary supplementation of Vitamin E is safe for the general population because these nutrients supply antioxidants, support functions for homeostasis, and protection against free radical damage (Hathcock et al., 2005). Vitamin E is among the most important a nutrient influencing the fish immune system, and the supply of vitamin $\mathrm{E}$ can reduce mortality and improve fish performance while increasing specific and nonspecific immune responses (Puangkaew et al., 2004).

The objective of this study was to evaluate the effect of vitamin $\mathrm{E}$ on growth performance, oxidative stress, hemato-biochemical and pathological alterations in Nile tilapia (Oreochromis niloticus) exposed to copper sulfate toxicity pre and post-challenge with Aeromonas hydrophila.

\section{MATERIALS AND METHODS}

\section{Chemicals}

Penta-hydrated copper sulfate $(\mathrm{CuSO} 4.5 \mathrm{H} 2 \mathrm{O}$, SYNTH, $99.9 \%$ purity) (Sigma-Aldrich Co., Germany). CAS Number 7758-99-8; EC Number: 231-847-6. Formula Weight: 294.69 $\mathrm{g} / \mathrm{mol}$. The amount of copper sulfate to be added to each aquarium was calculated after the volume of each aquarium. Fish were exposed to $0.32 \mathrm{mg} / \mathrm{L} \mathrm{CuSO} 4.5 \mathrm{H} 2 \mathrm{O}$ for 96 hours.

Vitamine E $1000 \mathrm{mg}$ soft gell capsules purchased from PHARCO Pharmaceutical, Alexandria Vit E capsules were used and dissolved in sunflower oil and mixed thoroughly with fish feed to obtain a dose of $600 \mathrm{mg} / \mathrm{kg}$ diet.

\section{Experimental design}

One hundred and Twenty Nile tilapia, $180 \pm 5 \mathrm{~g}$ mean body weight were randomly collected from earth ponds of Abbassa Fish Farm. After acclimatization for two weeks, fish were divided into four equal groups in three replicates (30 fish/group, $10 \mathrm{fish} /$ replicate) in twelve glasses aquaria $(60 \times 50 \times 70 \mathrm{~cm})$. The aquaria were supplied with chlorine-free water and continuous aeration using air pumping compressors. Water temperature was adjusted to $26^{\circ} \mathrm{C}$. The water of the aquaria was changed daily. The presented work was carried out in the Central Laboratory for Aquaculture Research (CLAR), Alabbassa, Abo-Hamad, Sharkia, Egypt, Agriculture Research Center, Ministry of Agriculture.

The experimental design consisted of four treatments: control, a control diet containing $30 \%$ crude protein was prepared (Table 1) and three experimental groups. The first group (G1) supplemented with a commercial diet (control group), the second group (G2) fed on a diet supplemented with $600 \mathrm{mg}$ of Vit $\mathrm{E} / \mathrm{kg}$ commercial diet according to Gammanpila et al. (2007), the third group (G3) exposed to of 
Copper sulfate pentahydrate $(\mathrm{CuSO} 4.5 \mathrm{H} 2 \mathrm{O})$ at a dose of $0.32 \mathrm{mg} / \mathrm{L}$ and supplemented with commercial diet. This dose was chosen according to Sharaf-Eldeen and Abdel-Hamid (2002). The fourth group (G4) diet supplemented with Vit E $(600 \mathrm{mg} / \mathrm{kg}$ diet $)$ and exposed to Copper sulfate at a dose of $0.32 \mathrm{mg} / \mathrm{L}$. Tilapia were fed with $3 \%$ of their total weight daily, three times a day for 40 days.

\section{Bacterial challenge}

After 30 days of the feeding trial, fish of each treatment were collected, pooled and randomly stocked at a density level of 10 fish per $100 \mathrm{~L}$ tanks. The challenge test was carried out using Aeromonas hydrophila isolated previously in the Department of Fish Health and Management, CLAR, Abbassa, Abo-Hammad, Sharqia, Egypt. For the challenge test, fish were challenged with pathogenic A. hydrophila, which was grown on nutrient broth for $24 \mathrm{hr}$ at $30^{\circ} \mathrm{C}$ in an incubator. Bacterial cells were then centrifuged at 3,000 g for $30 \mathrm{~min}$ to form pellets. The pellets were resuspended in $1.0 \mathrm{ml}$ of $0.1 \%$ peptone water and using a sublethal dose as described by Schäperclaus (1992) where a $0.1 \mathrm{ml}$ dose of 24 hr broth from virulent $A$. hydrophila $\left(5 \times 10^{5}\right.$ $\mathrm{CFU} / \mathrm{ml}$ ) was intraperitoneally (IP) injected. All fish groups were kept under observation for 10 days to record any abnormal clinical signs and daily fish mortality. A. hydrophila was reisolated from the liver, kidneys and spleen of the moribund and recently dead fish. The relative percent of fish survival (RPFS) was calculated at 10 days post-challenge according to Amend (1981) as follows:

RPFS $=100$ [1- (\% mortality in treated fish/ \% mortality in control fish)]

Table 1: Diet Composition:

\begin{tabular}{cc}
\hline Ingredients & Control \\
\hline & 0.0 \\
\hline Fish meal (HFM) & 6 \\
\hline Soybean meal (SBM) & 43.8 \\
\hline Ground corn (CNM) & 21.3 \\
\hline Wheat bran (WB) & 19.4 \\
\hline Codfish oil & 2.65 \\
\hline Corn oil & 1.35 \\
\hline Vitamins premix & 1.5 \\
\hline Minerals Premix & 1.5 \\
\hline Starch & 2.5 \\
\hline & Chemical analysis \\
\hline Dry matter & 91.01 \\
\hline Crude protein & 30.21 \\
\hline Crude fat & 3.48 \\
\hline Ash & 8.65 \\
\hline Fiber & 5.10 \\
\hline NFE & 52.56 \\
\hline GE (Kcal/100g) & 419.06 \\
\hline P/E ratio & 72.08 \\
\hline
\end{tabular}

\section{Clinical symptoms and postmortem examination of fish}

Through all the experimental period clinical signs and post mortem examination of monosex Oreochromis niloticus was performed according to (Austin and Austin, 1987).

\section{Growth performance}

At the end of the feeding trial and before the bacterial challenge, fish from each aquarium were harvested and weighed. Fish growth parameters and feed utilization were calculated as follows: where W1 and W2 are the initial and final weights, respectively. Weight gain 
$(\mathrm{g})=\mathrm{W} 2-\mathrm{W} 1$; Relative growth rate $=100$ (W2-W1/W1); Feed intake (g) feed/fish= the summation of feed consumed by fish throughout the experiment. Feed conversion ratio $(\mathrm{FCR})=$ Feed intake/ Fish weight gain; Feed Conversion Ratio (FCR) was calculated by dividing total feed intake per aquarium by the total body weight gain per the same aquarium, Feed Efficiency Ratio (FER) was calculated by dividing weight gain by feed intake (AOAC, 1990 and NRC, 1993).

\section{Sampling}

Blood and tissue samples were collected after (10, 20 and 30 days) of $\mathrm{CuSO} 4$ exposure and /or dietary Vit E treatments and a week post-challenge with $\mathrm{A}$. hydrophila. Blood samples were collected from 24 fish of each group. At each time interval, 6 blood samples were collected from the caudal vessels using disposable 3cc syringes and 21-gauge needles, (2 $\mathrm{ml} /$ fish). The first portion was collected with an anticoagulant $10 \quad \% \quad$ EDTA (ethylenediaminetetraacetate) for hematological studies, and the second portion of the blood sample was centrifuged at 3,000 rpm for $10 \mathrm{~min}$ for serum separation for biochemical analysis. Following the collection of blood samples, the fish were anesthetized by being immersed in ice water and in a saturated benzocaine solution and sacrificed by spinal cord transaction (AboAl-Ela et al., 2017).

\section{Hematological parameters}

The first portion of blood was used to determine hemoglobin $(\mathrm{Hb})$ concentration as described by Blaxhall and Daisley (1973). Packed cell volume (PCV), red blood cell (RBC) count, white blood corpuscles (WBC) count, differential count of leukocytes such as lymphocyte, neutrophil, monocyte, basophil and eosinophil according to Hrubec and Smith (2010).

\section{Biochemical parameters}

The non-hemolysed serum was collected and stored at $-20{ }^{\circ} \mathrm{C}$ until use. Levels of serum aspartate aminotransferase (AST), alanine aminotransferase (ALT) were estimated colorimetrically according to the method described by Sahoo et al. (2014), and serum creatinine was measured by the colorimetric method as described by Henry (1974) by Biodignostic Kits, Cairo, Egypt. Serum immunoglobulin $\mathrm{M}$ ( $\operatorname{IgM}$ ) levels measured using an Enzyme-Linked Immunosorbent Assay (ELISA) kit according to the method described by (Siwicki et al., 1993) by rayto ELIZA reader rt-2100c, MyBioSource.Com.

\section{Hepatic antioxidant assay}

Fish were anesthetized in anesthetic matter (75 ppm, benzocaine) and tissues were removed rapidly. Each fish was then dissected and the liver was extracted, cleaned by $0.9 \% \mathrm{NaCl}$ solution and kept at $-4^{\circ} \mathrm{C}$ until assayed. After that, each liver was homogenized in a cooled phosphate buffer saline $(\mathrm{pH} 7.0$ at a ratio 1: 10). The homogenate was then centrifuged $\left(13,000 \times \mathrm{g}\right.$ at $4^{\circ} \mathrm{C}$ for $\left.10 \mathrm{~min}\right)$ and the supernatant was pipetted and stored at $-4^{\circ} \mathrm{C}$ until analysis. Superoxide dismutase (SOD), catalase (CAT), and reduced glutathione (GSH) were determined colorimetrically in liver homogenates using the methods described by Gao et al. (1998), Aebi (1984), and Beutler et al. (1963) respectively by Biodignostic Kits, Cairo, Egypt.

\section{Histopathological examination:}

Specimens from different parts of livers, kidneys, and gills were collected after 10, 20, 30 of $\mathrm{CuSO} 4$ exposure and /or dietary Vit E treatments and 7 days post-challenge, then immediately fixed in $10 \%$ neutral buffered formalin, processed to obtain $4 \mu$ paraffin section. Sections were stained with Hematoxylin and Eosin stain for microscopic examination according to (Bancroft et al., 2013).

\section{Statistical analysis:}

Results were statistically analyzed using analyses of variance (F-test) followed by Duncan's multiple range test. A probability at a level of 0.05 or less was considered significant. Standard errors were also estimated using IBM SPSS statistics program version 20 (SPSS, 2006). 


\section{RESULTS}

1. Growth performance and feed efficiency: Fish exposed to copper sulfate (G3) exhibited a significant decrease in the means of weight gain (WG) and relative body weight gain (RBWG) and a slight decrease in feed efficiency ratio (FER) while induced a significant increase in feed conversion ratio
(FCR) compared to control group (G1) and were, while significantly increased in G4. In addition, fish fed on commercial diets supplemented with (600 mg of Vit E) $/ \mathrm{kg}$ significantly enhanced the feed conversion ratio and had the highest $\mathrm{WG}, \mathrm{RBWG}$ and FER (Table 2).

Table 2: Effect of $\mathrm{CuSO} 4$ exposure and /or dietary Vit E on weight gain, feed intake, feed conversion ratio and feed efficiency ratio of Nile tilapia.

\begin{tabular}{ccccc}
\hline Groups & $\begin{array}{c}\text { G1 } \\
\text { Control }\end{array}$ & $\begin{array}{c}\text { G2 } \\
\text { Vit E }\end{array}$ & $\begin{array}{c}\text { G3 } \\
\text { CuSO4 }\end{array}$ & $\begin{array}{c}\text { G4 } \\
\text { CuSO4+ Vit E }\end{array}$ \\
\hline $\begin{array}{c}\text { Fintial wt (g/fish) } \\
\begin{array}{c}\text { (g/fish) } \\
\text { (fishedy weight }\end{array}\end{array}$ & $185.00 \pm 1.5 \mathrm{a}$ & $182 \pm 1.53 \mathrm{ac}$ & $183.17 \pm 0.84 \mathrm{ac}$ & $187.17 \pm 0.44 \mathrm{ab}$ \\
\hline $\begin{array}{c}\text { Daily live body weight } \\
\text { gain (g/fish) }\end{array}$ & $38.17 \pm 1.24 \mathrm{c}$ & $63.07 \pm 1.79 \mathrm{a}$ & $29.17 \pm 1.19 \mathrm{~d}$ & $46.83 \pm 2.74 \mathrm{~b}$ \\
\hline $\begin{array}{c}\text { Relative body weight gain } \\
\text { (RBWG) }\end{array}$ & $20.62 \pm 0.54 \mathrm{c}$ & $34.64 \pm 1.28 \mathrm{a}$ & $15.91 \pm 0.62 \mathrm{~d}$ & $25.03 \pm 1.52 \mathrm{~b}$ \\
\hline Daily feed intake (g/fish) & $48.93 \pm 0.96 \mathrm{~b}$ & $57.94 \pm 1.27 \mathrm{a}$ & $38.27 \pm 1.09 \mathrm{c}$ & $52.71 \pm 0.76 \mathrm{~b}$ \\
\hline $\begin{array}{c}\text { Feed conversion ratio } \\
\text { (FCR) }\end{array}$ & $1.28 \pm 0.02 \mathrm{a}$ & $0.93 \pm 0.02 \mathrm{c}$ & $1.31 \pm 0.02 \mathrm{a}$ & $1.11 \pm 0.05 \mathrm{~b}$ \\
\hline $\begin{array}{c}\text { Feed efficiency ratio } \\
\text { (FER) }\end{array}$ & $77.95 \pm 1.11 \mathrm{c}$ & $107.19 \pm 2.06 \mathrm{a}$ & $76.16 \pm 1.07 \mathrm{c}$ & $90.44 \pm 3.98 \mathrm{~b}$ \\
\hline
\end{tabular}

Each value represents means \pm S.E.; $n=30$

Values with different letters in the same row represent significant difference at $\mathrm{P} \leq 0.05$ by Duncan multiple range test.

\section{Challenge test with Aeromonas hydrophila}

As shown in (Fig 1), the mortality \% was high in challenged fish treated with copper sulfate (G3) of 50\%, then, in (control) (challenged and not treated) (G1) and in challenged fish received (Vit.E+ copper sulfate) (G4) of $33.33 \%$ and $33.33 \%$ respectively after 10 days of challenge experiment. However, the lowest mortality $\%$ of $6.66 \%$ was recorded in challenged fish treated with Vit. E supplementation diets to provide maximum protection. The relative percent of fish survival (RPFS) equals 0,80 and 50 and 0 for control G1, G2, G3 and G4 respectively.

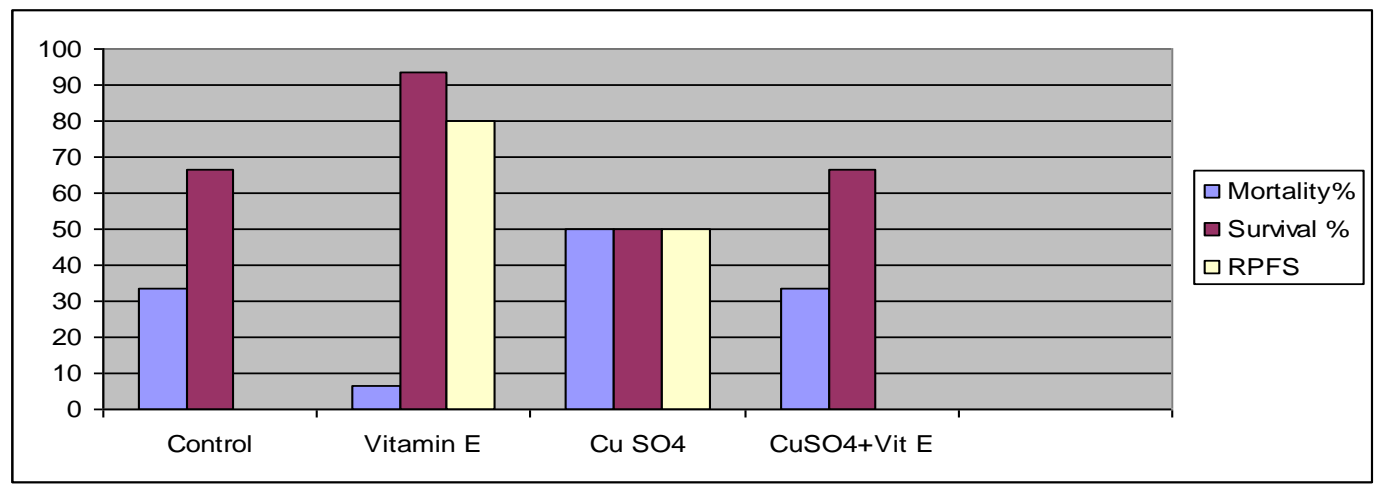

Fig. (1): Mortality $\%$, survival $\%$ and relative percent of fish survival of $O$. niloticus due to IP challenge with Aeromonas hydrophila $5 \times 10^{5} \mathrm{CFU} / \mathrm{ml}$ saline for 10 days after feeding experiment with diets containing Vit $\mathrm{E}(600 \mathrm{mg} / \mathrm{kg}$ diet and /or Copper sulfate $(0.32 \mathrm{mg} / \mathrm{L})$ exposure. 


\section{Hematological results}

Fish submitted to copper sulfate exhibited a significant decline in $\mathrm{Hb}, \mathrm{PCV}$ and RBCs in G3 in comparison to other tested groups pre and post-challenge throughout the experiment (Table, 3). In addition, WBCs, Neutrophil and lymphocytes count significantly increased in G3 pre and post-challenge. On the other hand, vitamin $\mathrm{E}$ supplementation significantly enhanced hematological parameters in G4 pre and post-challenge (Table, 3-4).

Table 3: Effect of CuSO4 and /or dietary Vit E erythrocytic indices. of Nile tilapia pre and postchallenge.

\begin{tabular}{|c|c|c|c|c|c|}
\hline Parameters & Time & $\begin{array}{c}\text { G1 } \\
\text { Control }\end{array}$ & $\begin{array}{c}\text { G2 } \\
\text { Vit E }\end{array}$ & $\begin{array}{c}\text { G3 } \\
\text { CuSO4 }\end{array}$ & $\begin{array}{c}\text { G4 } \\
\text { CuSO4+ Vit E }\end{array}$ \\
\hline \multirow[t]{4}{*}{ Hb (g/dL) } & $10^{\text {th }}$ days of treat & $10.59 \pm 0.32 \mathrm{a}$ & $11.60 \pm 0.55 \mathrm{a}$ & $6.5 \pm 0.32 \mathrm{c}$ & $8.60 \pm 0.33 \mathrm{~b}$ \\
\hline & $20^{\text {th }}$ days of treat & $10.48 \pm 0.32 \mathrm{a}$ & $11.03 \pm 0.65 \mathrm{ab}$ & $6.77 \pm 0.93 \mathrm{c}$ & $8.70 \pm 0.42 \mathrm{ac}$ \\
\hline & $30^{\text {th }}$ days of treat & $10.41 \pm 0.27 \mathrm{a}$ & $10.74 \pm 0.50 \mathrm{a}$ & $8.33 \pm 0.38 \mathrm{~b}$ & $9.07 \pm 0.09 \mathrm{~b}$ \\
\hline & 7 days post-infect & $10.66 \pm 0.36 \mathrm{a}$ & $8.57 \pm 0.35 \mathrm{~b}$ & $3.30 \pm 0.67 \mathrm{~d}$ & $6.33 \pm 0.43 \mathrm{c}$ \\
\hline \multirow[t]{4}{*}{ PCV (\%) } & $10^{\text {th }}$ days of treat & $38.00 \pm 2.65 \mathrm{a}$ & $39.33 \pm 0.88 \mathrm{ab}$ & $30.00 \pm 1.15 \mathrm{c}$ & $34.00 \pm 0.58 \mathrm{ac}$ \\
\hline & $20^{\text {th }}$ days of treat & $37.67 \pm 1.45 \mathrm{a}$ & $39.67 \pm 1.45 \mathrm{a}$ & $27.00 \pm 1.15 \mathrm{c}$ & $32.33 \pm 1.45 \mathrm{~b}$ \\
\hline & $30^{\text {th }}$ days of treat & $39.67 \pm 1.20 \mathrm{a}$ & $41.00 \pm 1.15 \mathrm{a}$ & $32.67 \pm 1.45 \mathrm{c}$ & $37.33 \pm 1.20 \mathrm{~b}$ \\
\hline & 7 days post-infect & $40.00 \pm 1.15 \mathrm{a}$ & $35.33 \pm 0.88 \mathrm{~b}$ & $24.67 \pm 1.45 \mathrm{~d}$ & $30.33 \pm 0.88 \mathrm{c}$ \\
\hline \multirow[t]{4}{*}{ RBC $\left(10^{6} / \mu L\right)$} & $10^{\text {th }}$ days of treat & $1.86 \pm 0.09 \mathrm{a}$ & $1.93 \pm 0.10 \mathrm{a}$ & $1.19 \pm 0.07 \mathrm{~b}$ & $1.66 \pm 0.12 \mathrm{a}$ \\
\hline & $20^{\text {th }}$ days of treat & $1.68 \pm 0.11 \mathrm{a}$ & $1.92 \pm 0.20 \mathrm{ab}$ & $1.00 \pm 0.01 \mathrm{~d}$ & $1.50 \pm 0.02 \mathrm{ac}$ \\
\hline & $30^{\text {th }}$ days of treat & $1.96 \pm 0.08 \mathrm{a}$ & $2.06 \pm 0.06 \mathrm{a}$ & $1.01 \pm 0.03 \mathrm{~b}$ & $1.53 \pm 0.13 \mathrm{c}$ \\
\hline & 7 days post-infect & $2.01 \pm 0.09 \mathrm{a}$ & $1.65 \pm 0.12 \mathrm{~b}$ & $1.00 \pm 0.01 \mathrm{~d}$ & $1.35 \pm 0.03 \mathrm{c}$ \\
\hline
\end{tabular}

Each value represents means \pm S.E.; $n=6$.

Values with different letters in the same row represent significant difference at $\mathrm{P} \leq 0.05$ by Duncan multiple range test.

Table 4: Effect of CuSO4 and /or dietary Vit E on some leucocytic indices of Nile tilapia pre and post-challenge.

\begin{tabular}{|c|c|c|c|c|c|}
\hline Parameters & Time $\quad$ Groups & $\begin{array}{c}\text { G1 } \\
\text { Control } \\
\end{array}$ & $\begin{array}{c}\text { G2 } \\
\text { Vit E }\end{array}$ & $\begin{array}{c}\text { G3 } \\
\text { CuSO4. }\end{array}$ & $\begin{array}{c}\text { G4 } \\
\text { CuSO4+ Vit E } \\
\end{array}$ \\
\hline WBC & $10^{\text {th }}$ days of treat & $21.67 \pm 0.45 \mathrm{~b}$ & $21.33 \pm 0.88 \mathrm{~b}$ & $25.33 \pm 0.16 \mathrm{a}$ & $22.33 \pm 0.88 \mathrm{~b}$ \\
\hline \multirow{3}{*}{$10^{3} / \mu \mathrm{L}$} & $20^{\text {th }}$ days of treat & $22.67 \pm 0.45 \mathrm{c}$ & $21.67 \pm 0.88 \mathrm{c}$ & $34.33 \pm 1.33 \mathrm{a}$ & $26.33 \pm 0.33 \mathrm{~b}$ \\
\hline & $30^{\text {th }}$ days of treat & $22.33 \pm 0.23 \mathrm{c}$ & $21.33 \pm 0.73 \mathrm{c}$ & $40.33 \pm 0.68 \mathrm{a}$ & $34.00 \pm 0.18 \mathrm{~b}$ \\
\hline & 7 days post-infect & $35.00 \pm 1.73 \mathrm{~b}$ & $23.00 \pm 0.58 \mathrm{c}$ & $44.33 \pm 1.33 \mathrm{a}$ & $36.00 \pm 1.06 \mathrm{~b}$ \\
\hline \multirow{4}{*}{$\begin{array}{c}\text { Neutrophils } \\
10^{3} / \mu \mathrm{L}\end{array}$} & $10^{\text {th }}$ days of treat & $6.67 \pm 1.86 \mathrm{~b}$ & $6.00 \pm 0.58 \mathrm{~b}$ & $9.00 \pm 0.15 \mathrm{a}$ & $6.80 \pm 0.15 \mathrm{~b}$ \\
\hline & $20^{\text {th }}$ days of treat & $6.67 \pm 0.67 \mathrm{~b}$ & $6.50 \pm 0.15 \mathrm{~b}$ & $10.33 \pm 0.88 \mathrm{a}$ & $6.33 \pm 0.88 \mathrm{~b}$ \\
\hline & $30^{\text {th }}$ days of treat & $7.00 \pm 0.30 \mathrm{c}$ & $7.67 \pm 0.76 \mathrm{c}$ & $16.67 \pm 0.88 \mathrm{a}$ & $11.33 \pm 0.45 \mathrm{~b}$ \\
\hline & 7 days post-infect & $14.33 \pm 0.33 \mathrm{~b}$ & $6.00 \pm 0.15 \mathrm{c}$ & $19 . .33 \pm 0.33 \mathrm{a}$ & $15.33 \pm 0.45 \mathrm{~b}$ \\
\hline \multirow{4}{*}{$\begin{array}{c}\text { Lymphocyte } \\
10^{3} / \mu \mathrm{L}\end{array}$} & $10^{\text {th }}$ days of treat & $15.00 \pm 0.08 \mathrm{~b}$ & $14.66 \pm 0.10 \mathrm{~b}$ & $17.00 \pm 0.53 \mathrm{a}$ & $15.00 \pm 0.30 \mathrm{~b}$ \\
\hline & $20^{\text {th }}$ days of treat & $15.67 \pm 0.33 \mathrm{~b}$ & $14.00 \pm 0.58 \mathrm{~b}$ & $22.33 \pm 0.86 \mathrm{a}$ & $21.33 \pm 0.88 \mathrm{a}$ \\
\hline & $3^{\text {th }}$ days of treat & $13.67 \pm 0.33 \mathrm{c}$ & $13.00 \pm 0.58 \mathrm{c}$ & $23.33 \pm 0.40 \mathrm{a}$ & $18.67 \pm 0.33 \mathrm{~b}$ \\
\hline & 7 days post-infect & $19.67 \pm 0.45 \mathrm{c}$ & $12.33 \pm 0.10 \mathrm{~d}$ & $24.00 \pm 0.46 \mathrm{a}$ & $20.33 \pm 0.20 \mathrm{~b}$ \\
\hline \multirow{4}{*}{$\begin{array}{c}\text { Monocyte } 10^{3} \\
/ \mu \mathrm{L}\end{array}$} & $10^{\text {th }}$ days of treat & $0.33 \pm 0.33 \mathrm{a}$ & $0 \pm 0 \mathrm{a}$ & $1.00 \pm 0.58 \mathrm{a}$ & $0.67 \pm 0.33 \mathrm{a}$ \\
\hline & $20^{\text {th }}$ days of treat & $0.67 \pm 0.33 \mathrm{a}$ & $0.33 \pm 0.67 \mathrm{a}$ & $1.33 \pm 0.33 \mathrm{a}$ & $1.33 \pm 0.33 \mathrm{a}$ \\
\hline & $30^{\text {th }}$ days of treat & $1.00 \pm 0.58 \mathrm{a}$ & $0 \pm 0 \mathrm{a}$ & $0.67 \pm 0.33 \mathrm{a}$ & $0.67 \pm 0.88 \mathrm{a}$ \\
\hline & 7 days post-infect & $1.67 \pm 0.18 \mathrm{a}$ & $1.00 \pm 0.58 \mathrm{a}$ & $1.67 \pm 0.33 \mathrm{a}$ & $1.00 \pm 0.76 \mathrm{a}$ \\
\hline \multirow{4}{*}{$\begin{array}{c}\text { Eosinophil } \\
10^{3} / \mu \mathrm{L}\end{array}$} & $10^{\text {th }}$ days of treat & $0 \pm 0$ & $0 \pm 0$ & $0 \pm 0$ & $0 \pm 0$ \\
\hline & $20^{\text {th }}$ days of treat & $0 \pm 0$ & $0 \pm 0$ & $0 \pm 0$ & $0 \pm 0$ \\
\hline & $30^{\text {th }}$ days of treat & $0 \pm 0$ & $0 \pm 0$ & $0 \pm 0$ & $0 \pm 0$ \\
\hline & 7 days post-infect & $0 \pm 0$ & $0 \pm 0$ & $0 \pm 0$ & $0 \pm 0$ \\
\hline \multirow{4}{*}{$\begin{array}{c}\text { Basophil } \\
10^{3} / \mu \mathrm{L}\end{array}$} & $10^{\text {th }}$ days of treat & $0 \pm 0$ & $0 \pm 0$ & $0 \pm 0$ & $0 \pm 0$ \\
\hline & $20^{\text {th }}$ days of treat & $0 \pm 0$ & $0 \pm 0$ & $0 \pm 0$ & $0 \pm 0$ \\
\hline & $30^{\text {th }}$ days of treat & $0 \pm 0$ & $0 \pm 0$ & $0 \pm 0$ & $0 \pm 0$ \\
\hline & 7 days post-infect & $0 \pm 0$ & $0 \pm 0$ & $0 \pm 0$ & $0 \pm 0$ \\
\hline
\end{tabular}

Each value represents means \pm S.E.; $n=6 \quad$ Values with different letters in the same row represent significant difference at $\mathrm{P} \leq 0.05$ by Duncan multiple range test. 


\section{Biochemical results}

A significant elevation in serum ALT, AST and creatinine were observed in $\mathrm{CuSO} 4-$ exposed fish G3 as compared to other tested groups pre and post-challenge throughout the experiment. These effects were significantly attenuated in fish fed on dietary vitamin E. On the other hand, immunoglobulin $M$ significantly decreased in $\mathrm{CuSO} 4$ exposed fish $\mathrm{G} 3$ in comparison to other tested groups pre and post-challenge. Nevertheless, vitamin E improved hepatorenal functions and immune response in G2 and $\mathrm{G} 4$ pre and post-challenge (Table, 4).

Table 5: Effect of CuSO4 exposure and /or dietary Vit E on some serum biochemical parameters in Nile tilapia pre and post- challenge.

\begin{tabular}{|c|c|c|c|c|c|}
\hline Parameters & Time & $\begin{array}{c}\text { G1 } \\
\text { Control }\end{array}$ & $\begin{array}{c}\text { G2 } \\
\text { Vit E }\end{array}$ & $\begin{array}{c}\text { G3 } \\
\text { CuSO4 }\end{array}$ & $\begin{array}{c}\text { G4 } \\
\text { CuSO4+ Vit E }\end{array}$ \\
\hline \multirow{4}{*}{$\begin{array}{l}\text { ALT } \\
(\mathbf{U} / \mathbf{L})\end{array}$} & $10^{\text {th }}$ days of treat & $9.94 \pm 0.11 \mathrm{c}$ & $8.91 \pm 0.58 \mathrm{c}$ & $27.98 \pm 0.95 \mathrm{a}$ & $14.11 \pm 0.75 \mathrm{~b}$ \\
\hline & $20^{\text {th }}$ days of treat & $7.47 \pm 0.53 \mathrm{c}$ & $6.68 \pm 0.45 \mathrm{c}$ & $15.36 \pm 0.70 \mathrm{a}$ & $11.13 \pm 0.62 \mathrm{~b}$ \\
\hline & $30^{\text {th }}$ days of treat & $10.40 \pm 0.57 \mathrm{~b}$ & $6.93 \pm 0.72 \mathrm{c}$ & $14.97 \pm 0.65 \mathrm{a}$ & $12.64 \pm 0.90 \mathrm{ab}$ \\
\hline & 7 days post-infect & $20.84 \pm 1.07 \mathrm{~b}$ & $15.13 \pm 0.66 \mathrm{c}$ & $28.20 \pm 1.65 \mathrm{a}$ & $30 . .29 \pm 1.03 \mathrm{a}$ \\
\hline \multirow{4}{*}{$\begin{array}{l}\text { AST } \\
(\mathbf{U} / \mathbf{L})\end{array}$} & $10^{\text {th }}$ days of treat & $24.80 \pm 0.69 \mathrm{c}$ & $23.01 \pm 0.53 \mathrm{c}$ & $64.25 \pm 6.35 \mathrm{a}$ & $47.94 \pm 2.00 \mathrm{~b}$ \\
\hline & $20^{\text {th }}$ days of treat & $22.06 \pm 1.68 \mathrm{c}$ & $19.07 \pm 0.69 \mathrm{c}$ & $46.26 \pm 1.17 \mathrm{a}$ & $36.65 \pm 1.58 \mathrm{~b}$ \\
\hline & $30^{\text {th }}$ days of treat & $21.30 \pm 3.35 \mathrm{c}$ & $20.01 \pm 1.05 \mathrm{c}$ & $42.76 \pm 2.29 \mathrm{a}$ & $31.84 \pm 1.71 \mathrm{~b}$ \\
\hline & 7 days post-infect & $21.51 \pm 1.23 \mathrm{~d}$ & $40.15 \pm 1.46 \mathrm{c}$ & $83.56 \pm 1.31 \mathrm{a}$ & $54.23 \pm 1.07 \mathrm{~b}$ \\
\hline \multirow{4}{*}{$\begin{array}{l}\text { Creatinine } \\
(\mathbf{m g} / \mathbf{d L})\end{array}$} & $10^{\text {th }}$ days of treat & $0.22 \pm 0.01 \mathrm{c}$ & $0.21 \pm 0.01 \mathrm{c}$ & $0.30 \pm 0.01 \mathrm{a}$ & $0.25 \pm 0.01 \mathrm{~b}$ \\
\hline & $20^{\text {th }}$ days of treat & $0.20 \pm 0.01 \mathrm{c}$ & $0.21 \pm 0.01 \mathrm{c}$ & $0.35 \pm 0.01 \mathrm{a}$ & $0.26 \pm 0.01 \mathrm{~b}$ \\
\hline & $30^{\text {th }}$ days of treat & $0.22 \pm 0.01 \mathrm{c}$ & $0.21 \pm 0.01 \mathrm{c}$ & $0.29 \pm 0.01 \mathrm{a}$ & $0.24 \pm 0.01 \mathrm{~b}$ \\
\hline & 7 days post-infect & $0.37 \pm 0.01 \mathrm{c}$ & $0.20 \pm 0.01 \mathrm{~d}$ & $0.53 \pm 0.02 \mathrm{a}$ & $0.44 \pm 0.01 \mathrm{~b}$ \\
\hline \multirow{4}{*}{$\begin{array}{c}\text { IgM } \\
(\mathrm{mg} / \mathrm{dL})\end{array}$} & $10^{\text {th }}$ days of treat & $381.33 \pm 4.17 \mathrm{a}$ & $383.33 \pm 3.58 \mathrm{a}$ & $140.00 \pm 1.89 \mathrm{c}$ & $203.67 \pm 4.18 b$ \\
\hline & $20^{\text {th }}$ days of treat & $378.33 \pm 4.81 \mathrm{~b}$ & $434.23 \pm 9.17 \mathrm{a}$ & $238.00 \pm 1.11 \mathrm{~d}$ & $287.00 \pm 3 . .50 \mathrm{c}$ \\
\hline & $30^{\text {th }}$ days of treat & $363.00 \pm 1.37 \mathrm{a}$ & $401.31 \pm 6.96 \mathrm{a}$ & $272.00 \pm 1.87 \mathrm{~b}$ & $353.33 \pm 4.53 \mathrm{a}$ \\
\hline & 7 days post-infect & $383.33 \pm 8.28 \mathrm{~b}$ & $428.35 \pm 3.02 \mathrm{a}$ & $243.67 \pm 4.48 \mathrm{~d}$ & $327.33 \pm 9.57 \mathrm{c}$ \\
\hline
\end{tabular}

Each value represents means \pm S.E.; $n=6 \quad$ Values with different letters in the same row represent significant difference at $\mathrm{P} \leq 0.05$ by Duncan multiple range test.

The enzymatic antioxidants, SOD and CAT levels were significantly increased in the liver of Nile tilia fish (G3) exposed to $\mathrm{CuSO} 4$ as compared to other tested groups pre and post-challenge throughout the experiment in a mechanism to cope with oxidative stress. However, the nonenzymatic antioxidant GSH level was significantly decreased in fish exposed to $\mathrm{CuSO} 4$ in comparison to all tested groups. On the other hand, vitamin E increased hepatic SOD, CAT and GSH concentration in fish challenged with Aeromonas hydrophila and exposed to $\mathrm{CuSO} 4$ in $\mathrm{G} 4$ in comparison to (G1) challenged and not treated (Table, 6). 
Table 6: Effect of CuSO4 exposure and /or dietary Vit E on hepatic antioxidants activities in Nile tilapia pre and post-challenge

\begin{tabular}{|c|c|c|c|c|c|}
\hline Parameters & Time & $\begin{array}{c}\text { G1 } \\
\text { Control }\end{array}$ & $\begin{array}{c}\text { G2 } \\
\text { Vit E }\end{array}$ & $\begin{array}{c}\text { G3 } \\
\text { CuSO4 }\end{array}$ & $\begin{array}{c}\text { G4 } \\
\text { CuSO4+ Vit E }\end{array}$ \\
\hline \multirow{4}{*}{$\begin{array}{c}\text { SOD } \\
(\mu \mathrm{mol} / \mathrm{g})\end{array}$} & $10^{\text {th }}$ days of treat & $13.83 \pm 1.01 \mathrm{~d}$ & $31.33 \pm 1.20 \mathrm{c}$ & $42.33 \pm 1.45 \mathrm{a}$ & $37.67 \pm 1.45 \mathrm{~b}$ \\
\hline & $20^{\text {th }}$ days of treat & $18.33 \pm 0.88 \mathrm{~d}$ & $19.67 \pm 0.88 \mathrm{c}$ & $27.33 \pm 1.45 \mathrm{a}$ & $25.67 \pm 1.20 \mathrm{~b}$ \\
\hline & $30^{\text {th }}$ days of treat & $15.33 \pm 1.45 \mathrm{~b}$ & $17.67 \pm 1.45 \mathrm{~b}$ & $23.00 \pm 2.08 \mathrm{ab}$ & $27.57 \pm 1.55 \mathrm{a}$ \\
\hline & 7 days post-infect & $14.33 \pm 1.45 \mathrm{c}$ & $14.47 \pm 0.48 \mathrm{c}$ & $41.33 \pm 0.88 \mathrm{a}$ & $34.33 \pm 2.33 \mathrm{~b}$ \\
\hline \multirow{4}{*}{$\begin{array}{r}\text { CAT } \\
(\mathrm{mmol} / \mathrm{g})\end{array}$} & $10^{\text {th }}$ days of treat & $28.33 \pm 2.40 \mathrm{~d}$ & $55.67 \pm 1.20 \mathrm{c}$ & $73.33 \pm 2.40 \mathrm{a}$ & $64.67 \pm 2.03 \mathrm{~b}$ \\
\hline & $20^{\text {th }}$ days of treat & $27.33 \pm 5.04 \mathrm{~b}$ & $28.00 \pm 1.53 \mathrm{~b}$ & $54.67 \pm 2.60 \mathrm{a}$ & $47.00 \pm 2.08 \mathrm{a}$ \\
\hline & $30^{\text {th }}$ days of treat & $22.33 \pm 1.45 \mathrm{c}$ & $31.67 \pm 2.19 \mathrm{~b}$ & $42.67 \pm 1.45 \mathrm{a}$ & $24.67 \pm 2.40 \mathrm{c}$ \\
\hline & 7 days post-infect & $31.33 \pm 1.45 \mathrm{c}$ & $39.33 \pm 2.60 \mathrm{~b}$ & $73.67 \pm 2.40 \mathrm{a}$ & $39.00 \pm 0.58 \mathrm{~b}$ \\
\hline \multirow{4}{*}{$\begin{array}{c}\text { GSH } \\
(\mu \mathrm{mol} / \mathrm{g})\end{array}$} & $10^{\text {th }}$ days of treat & $3.13 \pm 0.50 \mathrm{~b}$ & $11.17 \pm 0.31 \mathrm{a}$ & $3.23 \pm 0.22 \mathrm{~b}$ & $11.03 \pm 0.17 \mathrm{a}$ \\
\hline & $20^{\text {th }}$ days of treat & $4.42 \pm 0.22 \mathrm{~b}$ & $4.97 \pm 0.12 b$ & $2.38 \pm 0.14 \mathrm{c}$ & $6.46 \pm 0.33 \mathrm{a}$ \\
\hline & $30^{\text {th }}$ days of treat & $4.62 \pm 0.45 \mathrm{ab}$ & $4.77 \pm 0.22 \mathrm{a}$ & $3.50 \pm 0.17 \mathrm{~b}$ & $4.22 \pm 0.39 \mathrm{ab}$ \\
\hline & 7 days post-infect & $3.72 \pm 0.12 \mathrm{~d}$ & $9.72 \pm 0.51 \mathrm{a}$ & $5.13 \pm 0.12 \mathrm{c}$ & $6.90 \pm 0.21 \mathrm{~b}$ \\
\hline
\end{tabular}

Each value represents means \pm S.E.; $n=6 \quad$ Values with different letters in the same row represent significant difference at $\mathrm{P} \leq 0.05$ by Duncan multiple range test.

\section{Clinical signs}

Infected fish in $\mathrm{G} 3$ exposed to $\mathrm{CuSO} 4$ showed typical $A$. hydrophila clinical signs and post mortem lesions (exophthalmia, hemorrhages and erosion in fins, scales desquamation, severe enteritis with yellow mucous in the intestinal lumen, congested liver with an enlarged gall bladder). However, Infected fish in G2 indicated a characteristic gross morphological change with extremely enlarged liver with a pale yellowish color tint and inflamed other internal structures, with mucoid materials on the congested gills and Infected fish in G4 revealed morphological changes corresponding and nearly similar to the previously mentioned $\mathrm{G} 2$ at the same time period, regarding the gills, skin, fins, internal organs and whole body musculature.

\section{Pathological Findings}

\section{1. Vitamin E- treated group}

Examined organs of this group at 10, 20 and 30 days from the beginning of the experiment demonstrated apparently normal naked eye (macroscopic) anatomical morphological appearance of the organs with regard to the skin and scales healthy status, fins, operculum, gills and all internal structures (Plate 1. Fig. A). Histopathologically all examined organs were apparently normal. All structures of the gills including arches, primary filaments, secondary lamellae and their epithelial linings beside the mucus cells, chloride cells and pillar cells were apparently normal. Variable numbers of immuno-functional eosinophilic granular cells were seen infiltrating the gill arches lamina properia. The filament and lamellar capillaries were normal and the gill raker structures were well arranged and hito-morphologically normal, comprising an average number of mucus-secreting cells (Plate1. Fig. 1, 2). The hepato-portal structures and hepatocytes were well arranged with good histo-morphological structural and physio-histological properties (Plate 1. Fig. 3, 4). The renal structures including the tubular, glomerular, vascular and the minimally presented melano-macrophages were hiso-morphologically normal (Plate 1. Fig. 5, 6).

One week post-challenged fish (beginning from the end of the $30^{\text {th }}$ day of the experiment). Examined organs pointed out a characteristic gross morphological change with extremely enlarged liver having a pale yellowish color tint and inflamed other internal structures, with mucoid materials on the congested gills (Plate 2. Fig. B). Histopathologically there was partial denudation of the gill filament lamellae with focal aggregations of round cells, eosinophilic granular cells, chloride cells and variable number of mucus-secreting cells, particularly at the basal and terminal ends of the gill filaments and in the lamina properia of 
the gill arches (Plate 2. Figs. 7, 8). The liver showed focal degenerative and necrotic changes in the hepatocytes (Plate 2. Figs. 9, 10) and the kidneys revealed marked interstitial round cells aggregations, focal degenerative and necrotic changes beside focal renal tubular proliferation (plate 2. Figs. 11, 12).

\section{2. Fish intoxicated with $0.32 \mathrm{mg} / \mathrm{L}$ Copper sulfate}

Examined organs at 10, 20 and 30 days from the beginning of the experiment pointed out characteristic gross morphological changes represented by xerophthalmia, hyperemic skin at the ventral body aspect, general cachexia and partial loss of body musculature (Plate 3 . Fig. C). Histopathological examination of gills at 10 days showed partial destruction and loss of the gill filament epithelium, an inflammatory exudative reaction involving the gill arches and the primary gill filaments besides infiltration of eosinophilic granular cells. The liver showed degenerative changes and vacuolar degeneration in the hepatopancreatic acini. The kidneys revealed highly dilated capillaries, degenerated renal tubules beside lobulated and shrinking or hypocellular glomeruli. Characteristic round cell aggregations in the gill arches beside marked mucinous degeneration and increased number of mucus-secreting cells in the gill filaments were seen at the $20^{\text {th }}$ day of the experiment. At this time the liver denoted marked hepatocellular degeneration and the kidneys showed renal tubular degeneration and mildly lobulated glomeruli. On the $30^{\text {th }}$ day of the experiment, the gills showed pathognomonic telangiectasia of the secondary gill filament capillaries (Plate 3. Figs.13, 14), the liver showed vacuolated hepatocytes (VHC). (Plate 3. Figs. 15, 16), but the renal changes were marked and represented by multifocal tubular necrosis and lobulation or shrinkage of the glomeruli (Plate 3. Figs. 17, 18).

One week post-challenged fish (beginning from the end of the $30^{\text {th }}$ day of the experiment). Examined organs cleared out a peculiar gross morphological changes, besides the previously mentioned changes there were gill inflammatory changes and presence of a large amount of mucoid materials on their surfaces, inflamed internal organs with the transformation of the omental fat into slimy mucoid material (serous atrophy) (Plate 4. Fig. D). Histopathologically the gills revealed marked inflammatory and destructive changes with characteristic mucinous degeneration and formation of mucin-cysts (plate 4. Fig. 19, 20) The liver showed hepatocellular degeneration besides pancreatic acinar disorganization and destructive changes (necrosis) together with the focal aggregation of melano-macrophages (Plate 4. Fig. 21, 22). The kidneys showed glomerular shrinkage, tubular necrosis and focal aggregation of melano-macrophages. (Plate 4. Fig. 23, 24).

\section{3. Fish treated with Vit. $E$ and exposed to Copper sulfate (CuSO4):}

Examined organs of this group at 10, 20 and 30 days from the beginning of the experiment revealed mild gross morphologic abnormalities as mild xerophthalmic changes in a few fish, mildly hyperemic gill filament and insignificant loss of the body musculature (Plate 5. Fig. E) Histopathologic examination of the gills at 10 days revealed apparently normal gill filaments with a few reactive mucus-secreting cells, sometimes with the formation of mucinous cysts. The liver and kidney showed few vacuolar degenerative changes. Twenty days from the beginning of the experiment examined gills showed mild telangiectatic capillaries involving the primary gill filaments and the secondary lamellar filament and increased number of mucussecreting cells, particularly in the secondary gill lamellae (Plate 5. Figs. 25, 26). Hepatic changes were minimal as a few vacuolated hepatocytes. The hepato-pancreatic acini were apparently normal and pathophysiologically reactive (Plate 5. Figs. 27, 28). The kidney demonestrated a few degenerated and necrotic renal tubules and lobulated glomeruli among normal other structures (Plate 5 Figs. 29, 30). On the $30^{\text {th }}$ day, gills were histopathologically normal apart of a very few telangiectatic capillaries involving the secondary lamellar filament and focal infiltration of round cells (lymphocytes) and eosinophilic granular cells at the tips of some gills. The liver showed some dispersed vacuolated cells among apparently normal hepatic parenchyma. The 
kidney appeared normal with a few distributed melano-macrophages.

One week post-challenged fish (beginning from the end of the $30^{\text {th }}$ day of the experiment). Examined organs pointed out morphological changes corresponding and nearly similar to the previously mentioned $\mathrm{G} 2$ at the same time period, regarding the gills, skin, fins, internal organs and whole body musculature. Histopathologically examined gills revealed generalized shortening and epithelial denudation of the lamellar filaments together with focal round cells and eosinophilic granular cells aggregation, mucus-secreting cells proliferation and consequent gill filament adhesion (proliferative gill reaction) (Plate 6. Figs. 31, 32). The liver showed focal hepatocyte degeneration and interstitial round cell aggregations. (Plate 6. Fig. 33, 34). The kidney declared characteristic renal tubular degenerative and early necrotic changes beside focal interstitial round cell aggregations (Plate 6. Figs. 35, 36).

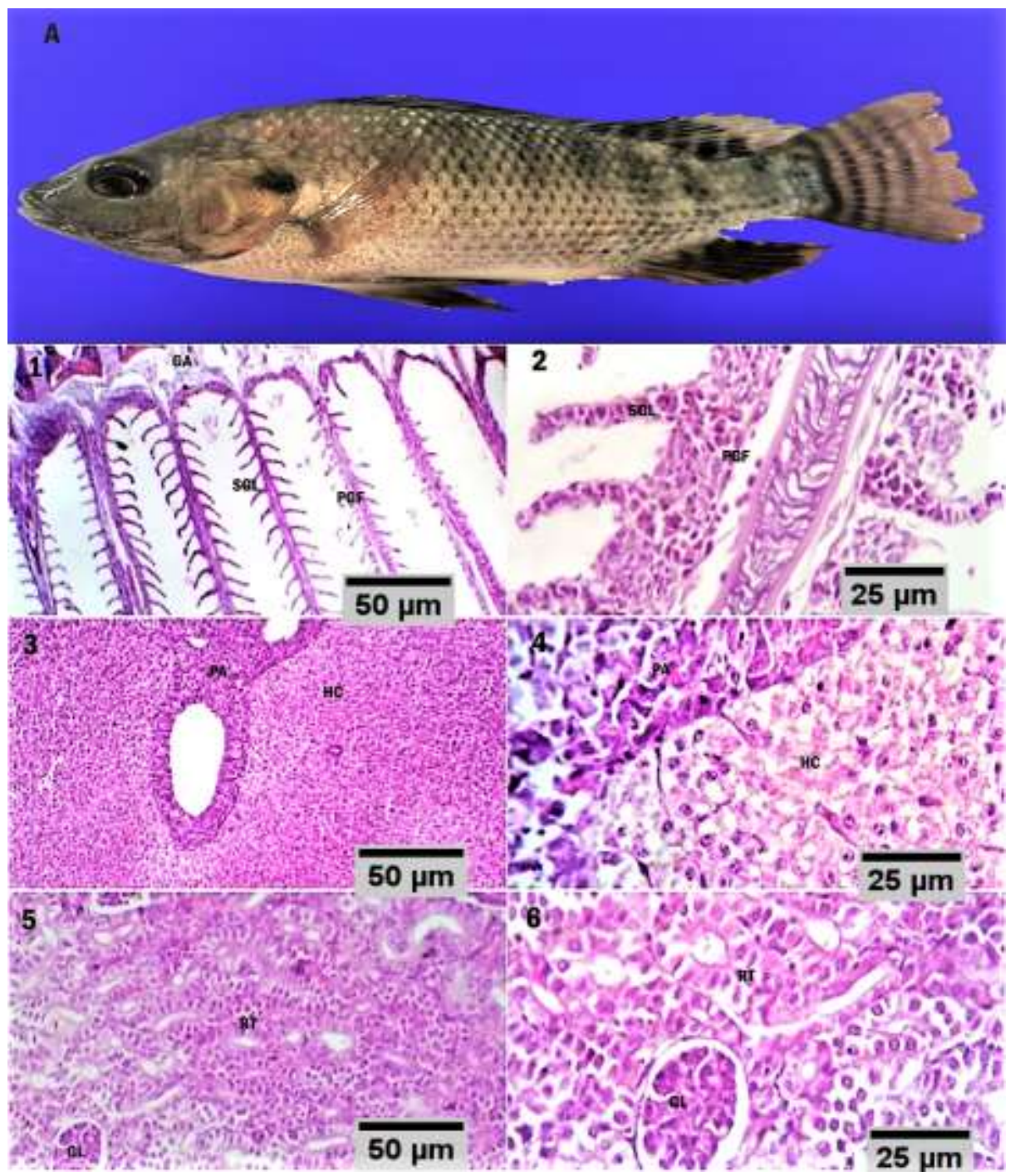

Plate 1. Fish of Vit. E $(600 \mathrm{mg} / \mathrm{Kg})$ treated group, 10 days from beginning of the experiment.

Fig. A. Normal gross morphology of the external structures, including skin, scales, fins, operculum, eyes and healthy status.

Figs. 1, 2: Gills showing a normal histo-morphology of the gill arch (GA), primary gill filaments (PGF), secondary gill lamellae (SGL) and mildly dilated branchial capillaries. (Scale bares $50 \mathrm{um}, 25$ um)

Figs. 3, 4: Liver, showing normal histo-morphology of the hepato-portal area (HPA) and hepatocytes (HC) (Scale bares 50 um, 25 um).

Figs. 5, 6: Kidney showing apparently normal tubular (RT) and glomerular structures (GL). (Scale bars (Scale bares $50 \mathrm{um}, 25 \mathrm{um}$ ). 


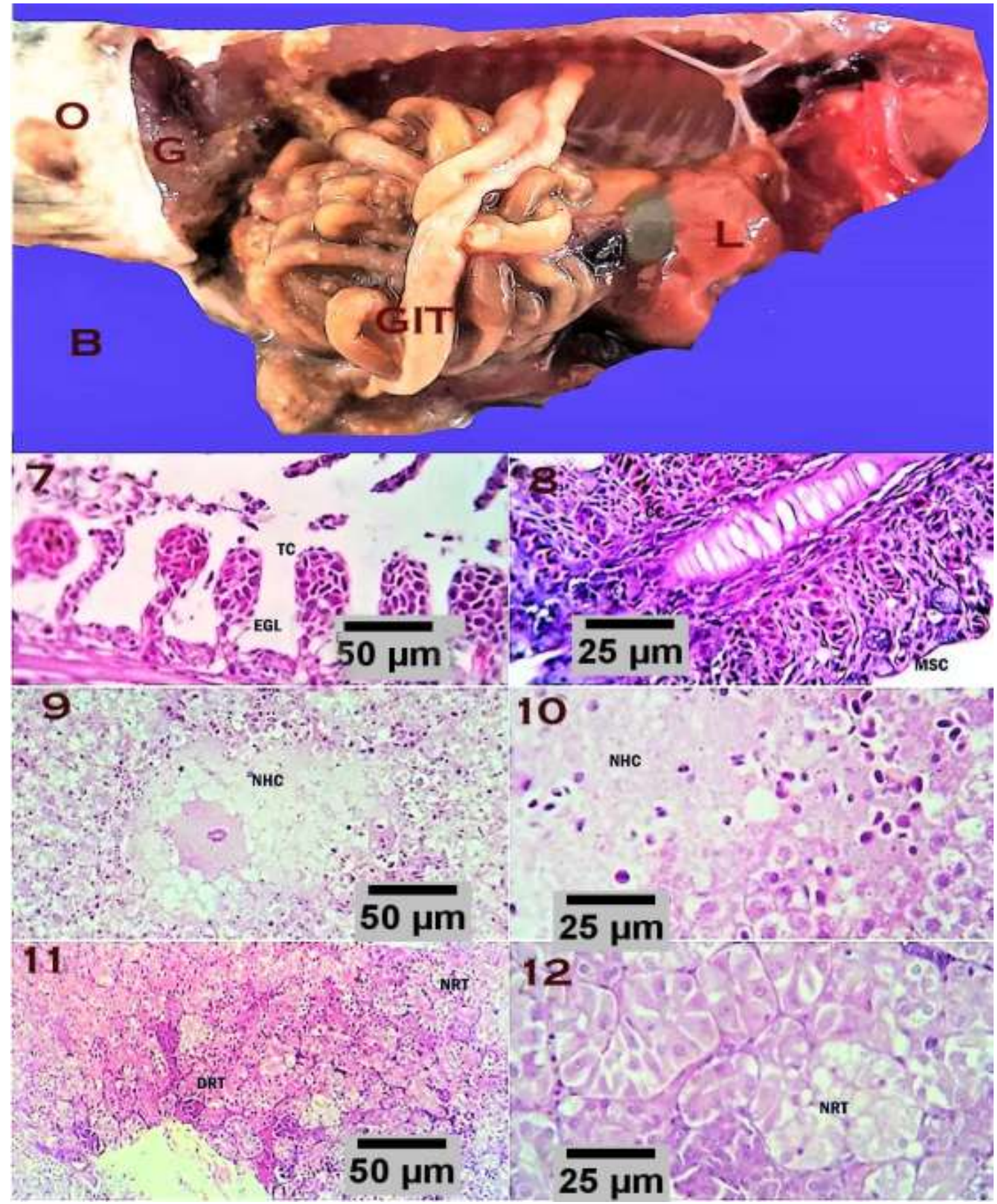

Plate 2: Fish of Vit. E-treated group, One-week post-challenged (beginning from the end of the $30^{\text {th }}$ day of the experiment).

Fig.B: showing characteristic gross morphological changes with enlarge pale-colored liver with a fine grayish white nodular surface and inflamed internal organs (GIT) with the presence of numerous grayish white fine nodules.

Figs. $(7,8)$ : showing gills with inflammatory changes, marked capillary telangiectiasis (TC) and increased number of highly activated (EGL), hypertrophied mucus-secreting cells (MSC). (Scale bars 50 um, 25 um.)

Figs. (9, 10): liver showing focal necrotic areas, partially replaced by erythrocytes and leucocytes (NHC). (Scale bars $50 \mathrm{um}, 25 \mathrm{um}$.)

Figs. $(11,12)$ : kidney showing multi-focal tubular degenerative (DRT) and early necrotic changes (NRT). (Scale bars $50 \mathrm{um}, 25 \mathrm{um}$.). 


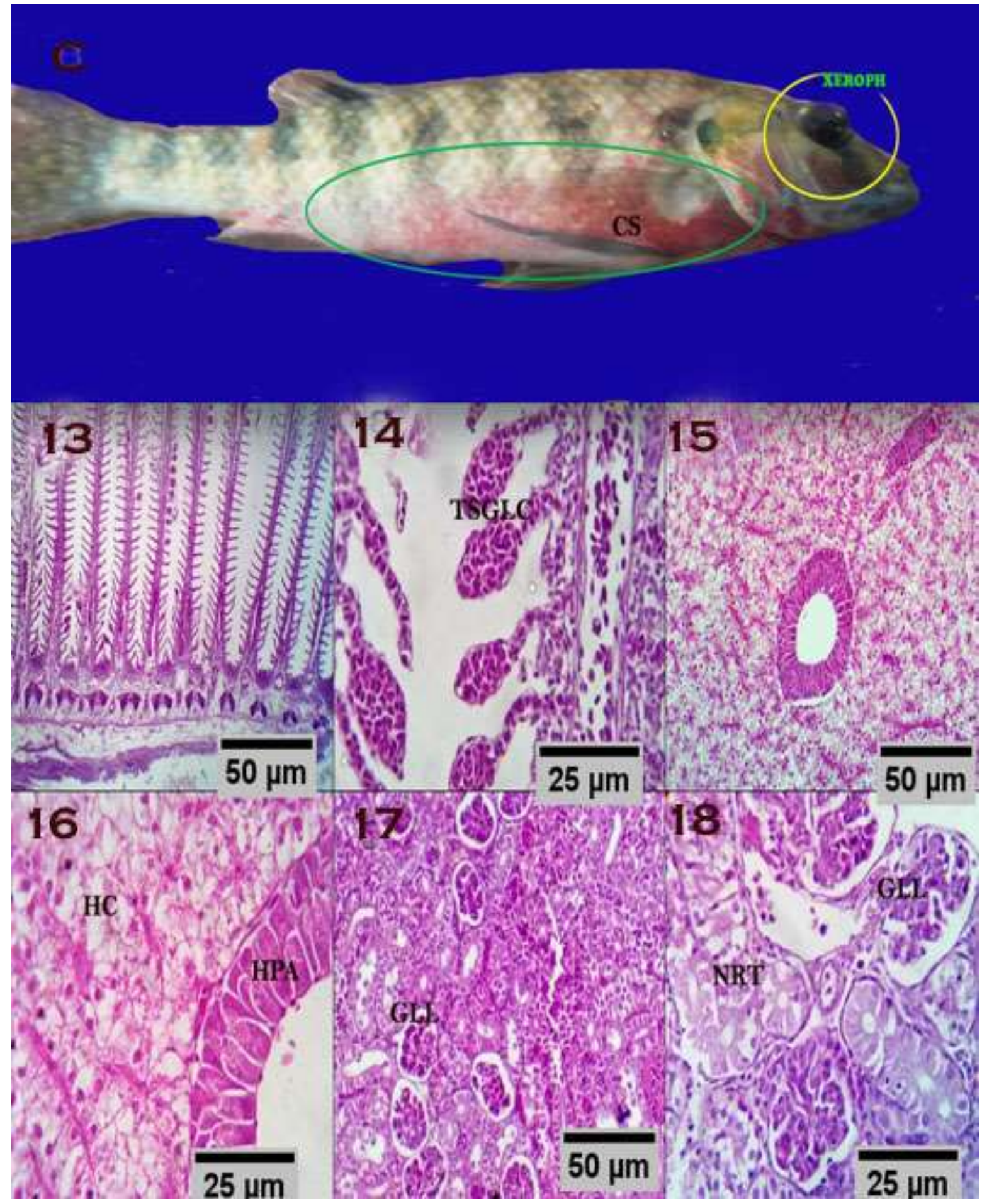

Plate 3: Fish of Copper sulfate (CuSO4) $(0.32 \mathrm{mg} / \mathrm{L})$ treated group, 30 days from the beginning of the experiment.

Fig. C: Showing xerophthalmia (XEROPH), hyperemic skin (CS) at the ventral body aspect, general cachexia and partial loss of body musculature.

Figs. $(13,14)$ : Gills showing pathognomonic telangiectasia of the secondary gill filament capillaries (TSGLC). (Scale bars $50 \mathrm{um}, 25 \mathrm{um}$.)

Figs. (15, 16): Liver showing vacuolated hepatocytes (VHC). (Scale bars $50 \mathrm{um}, 25 \mathrm{um}$.). Figs. (17, 18): Kidney showing. multifocal tubular necrosis (NRT) and shrinkage of the glomeruli (GLL). (Scale bars $50 \mathrm{um}, 25 \mathrm{um}$ ). 


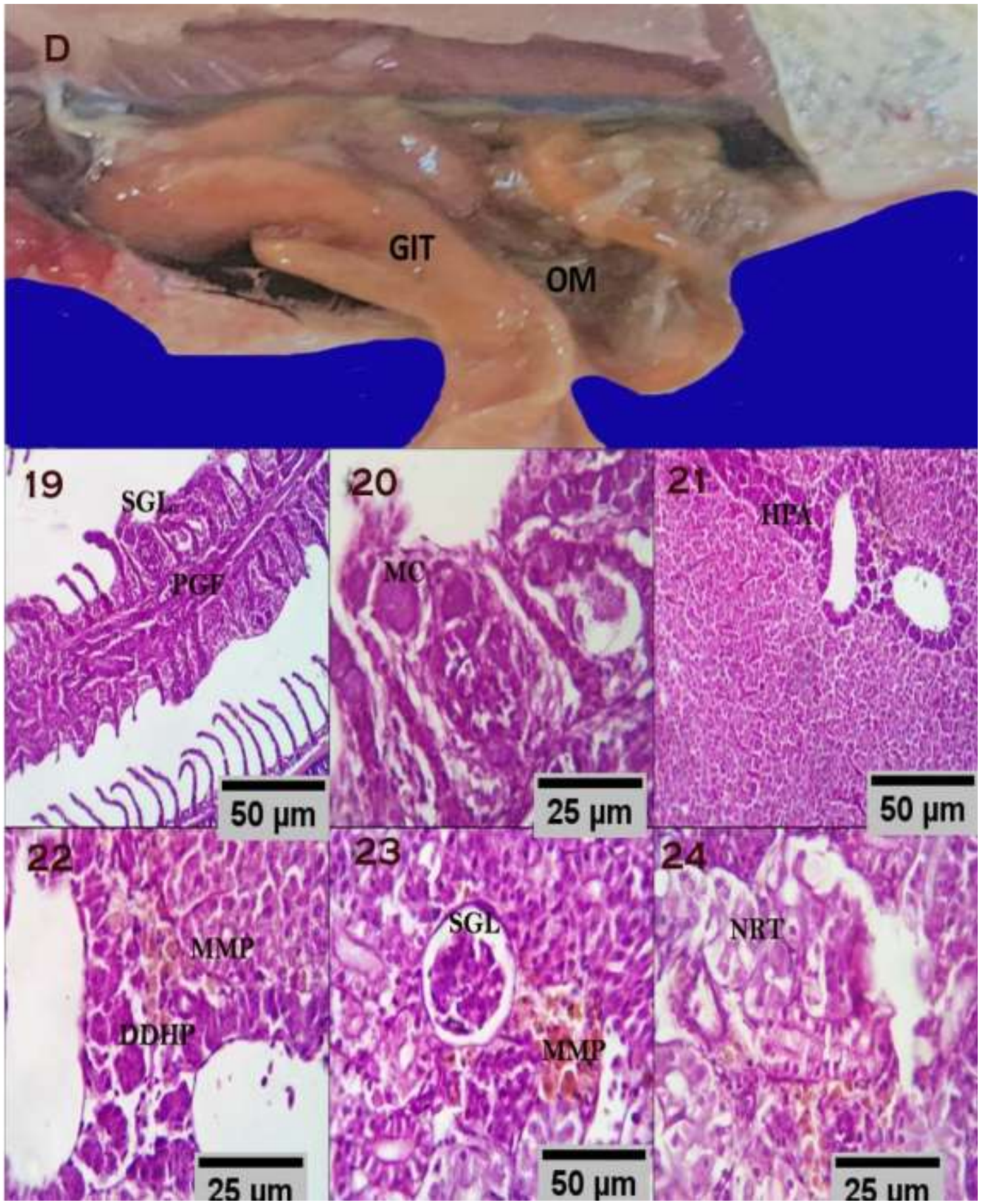

Plate 4: Fish of Copper sulfate $(\mathrm{CuSO} 4)(0.32 \mathrm{mg} / \mathrm{L})$ treated group, one-week post-challenged (beginning from the end of the $30^{\text {th }}$ day of the experiment).

Fig. D: Showing inflamed internal organs (GIT) with the transformation of the omental fat (OM) into slimy mucoid material (serous atrophy)

Figs. (19,20): Gills showing marked inflammatory and destructive changes with characteristic mucinous degeneration and formation of mucin- cysts (MC). (Scale bars $50 \mathrm{um}, 25 \mathrm{um}$.)

Figs. (21,22): Liver showing hepatocellular degeneration beside pancreatic acinar disorganization and destructive changes (necrosis) (DDHP) together with the focal aggregation of melano-macrophages (MMP). (Scale bars 50 um, 25 um.)

Figs. (23, 24): Kidney showing glomerular shrinkage (SGL), tubular necrosis (NRT) and focal aggregation of melano-macrophages (MMP) (Scale bars $50 \mathrm{um}, 25 \mathrm{um}$.). 


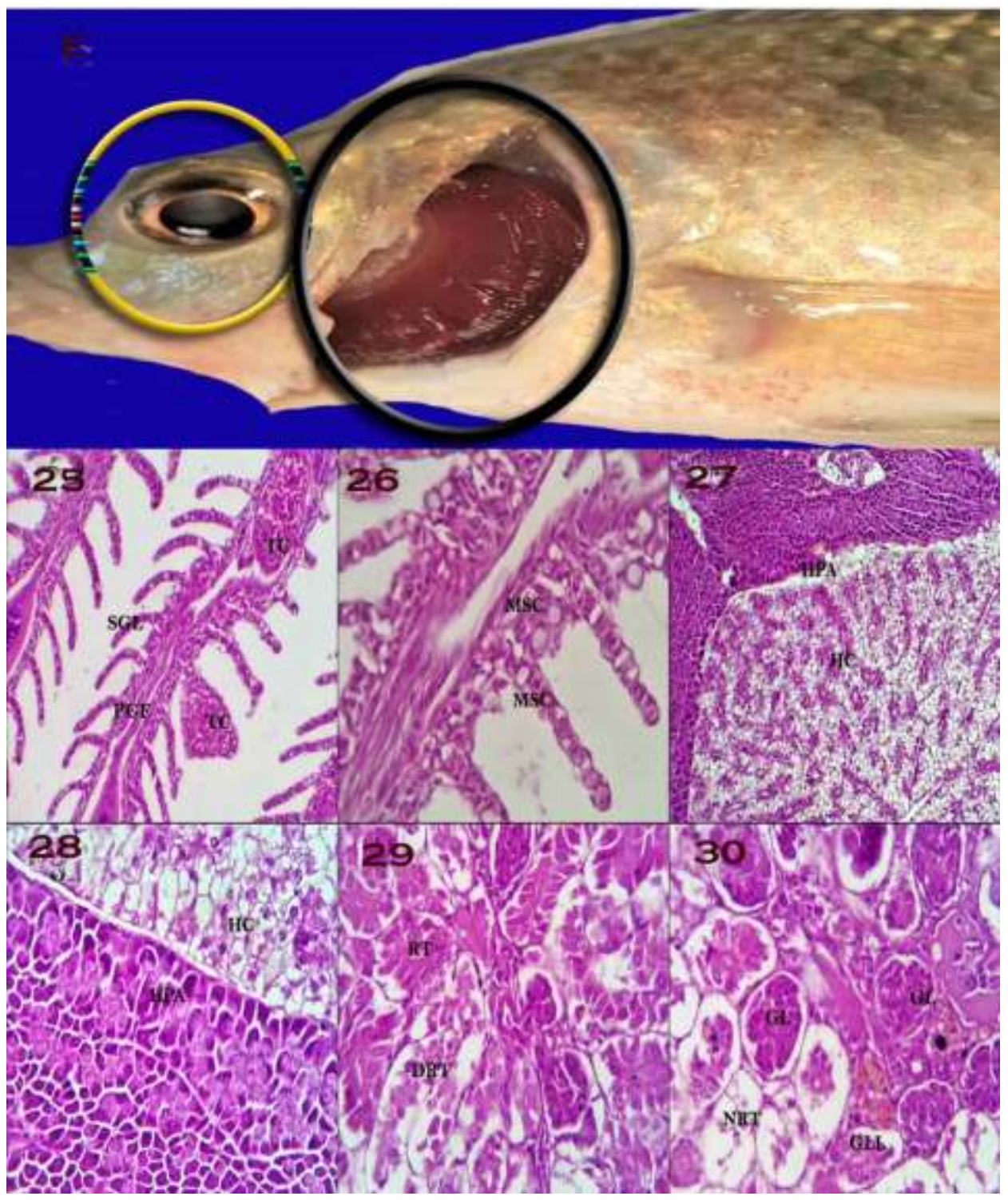

Plate 5: Fish treated with Vit. E (600 mg/ Kg) and Copper sulfate (CuSO4) (0.32 mg/ L), 20 days from the beginning of the experiment

Fig. E: Showing xerophthalmia (circle), mild hyperemic gill filament (circle) and insignificant loss of the body musculature.

Figs. (25,26): Gills showing mild telangiectatic capillaries involving the primary gill filaments and the secondary lamellar filament (TC) and increased number of mucus-secreting cells (MSC), particularly in the secondary gill lamellae (Scale bars $50 \mathrm{um}, 25 \mathrm{um}$.). Figs. (27, 28): Liver showing vacuolation of some hepatic cells (Scale bars $50 \mathrm{um}, 25 \mathrm{um}$ ). Figs. (29, 30): Kidney showing few degenerated (DRT) and necrotic renal tubules (NRT) and lobulated glomeruli. (GLL). (Scale bars 50 um, 25 um). 


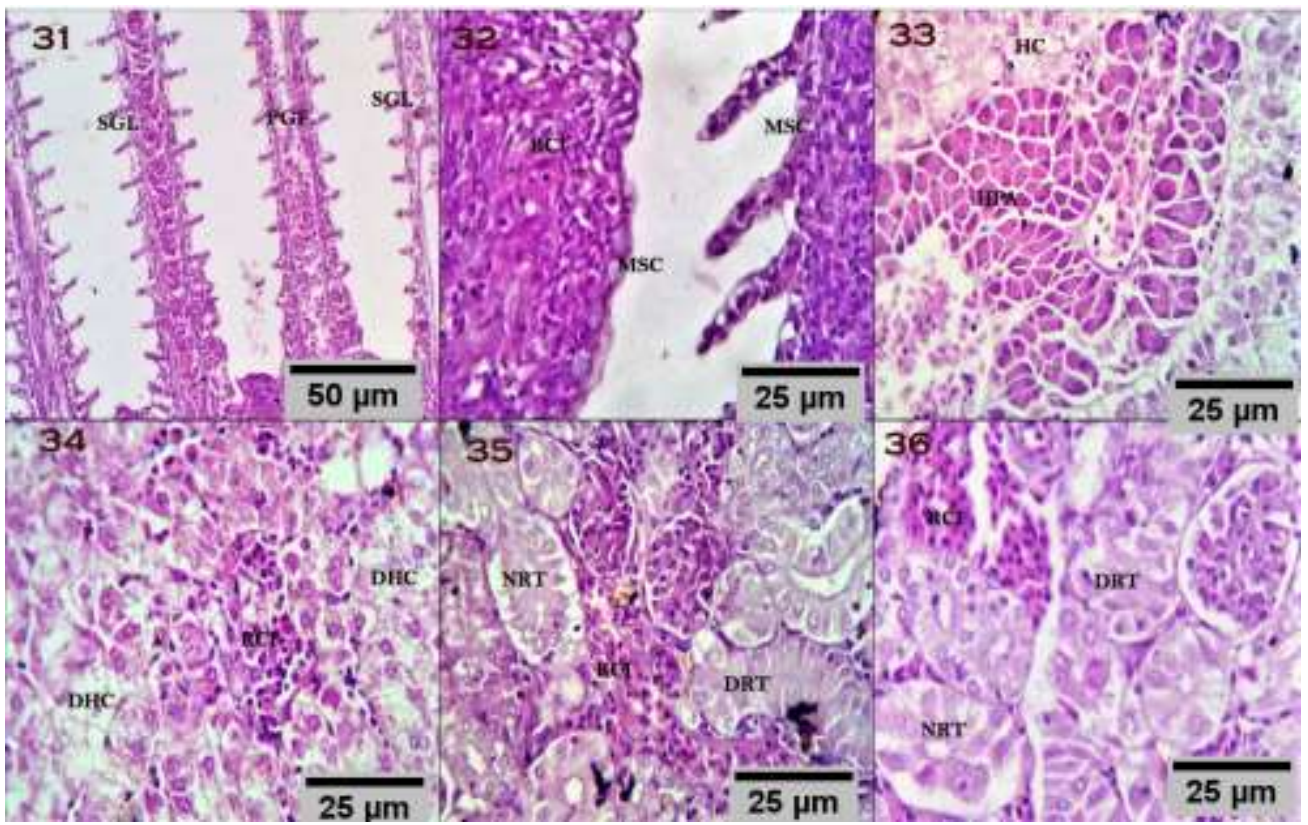

Plate 6: Fish treated with Vit. E $(600 \mathrm{mg} / \mathrm{Kg})$ and Copper sulfate $(\mathrm{CuSO} 4)(0.32 \mathrm{mg} / \mathrm{L})$. One week post-challenged (beginning from the end of the $30^{\text {th }}$ day of the experiment).

Figs. (31, 32): Gills showing generalized shortening and epithelial denudation of the lamellar filaments (SGL) together with focal round cells (RCI) and eosinophilic granular cells aggregation (EGC), mucus-secreting-cells (MSC) proliferation. ( Scale bars 50 um, 25 um.)

Figs. (33, 34): Liver showing focal hepatocytes degeneration (DHC) and interstitial round cell aggregations (RCI). (Scale bars 50um, $25 \mathrm{um}$.)

Figs. (35, 36): Kidney showing. renal tubular degenerative (DRT) and early necrotic changes (NRT) beside focal interstitial round cell aggregations (RCI). (Scale bars 50um, $25 \mathrm{um}$.).

\section{DISCUSSION}

Most of the heavy metal ions exhibit toxicity through the formation of coordination complexes and clusters in the animal cells. A low concentration of heavy metals may cause chronic stress that might not kill the fish by itself but decrease its size and body weight, therefore reducing their capability to fight for food and habitat. Fish have a tendency to bioaccumulate heavy metals and human beings can be at serious risk through contamination of the food chain (Rajamanickam, 2008). Heavy metal contamination usually causes depletion in feed utilization in fish and such disturbance may result in reduced fish metabolic rate and hence causing a reduction in their growth. Growth is a sensitive and reliable endpoint in chronic toxicological investigations. $\mathrm{Cu}$ is one of the most toxic metals to fish. It affects various blood parameters, growth, behavior and enzyme activity in spite of its important role in metabolism as an essential metal for all organisms (Gharedaashi et al., 2013). The 96 h-LC50 of CuSO4 is $12.85 \mathrm{mg} / \mathrm{L}$ in Nile tilapia according to (Mutlu et al., 2015). Copper toxicity occurs when a specific amount of metal binds to physiologically active biological membranes, generally outcompeting cations injuring the physiological mechanism (Farhangi and Jafaryan, 2019). In accordance with the present study, El-Keredy et al. (2017) observed a significant reduction in the final weight, total gain, weight gain $\%$, relative growth rate and a significant deterioration in feed conversion ratio and protein efficiency ratio in fish exposed to copper.

Supplementation of dietary vitamin E improved whole-body fatty acids of fish like the a-linolenic acid (ALA) and eicosapentaenoic acid (EPA) contents in fish. On the other hand, dietary supplementation of vitamin $\mathrm{E}$ (100 or $200 \mathrm{mg} / \mathrm{kg}$ diet) can enhance the growth performance in juvenile olive flounder intoxicated with mercury (Moniruzzaman et al., 2017). The present results recorded improved growth performance with the addition of the antioxidant (Vit E) and that could have potential use as a preventive or 
therapeutic measure in $\mathrm{Cu}$ - exposed fish. Fish received copper sulfate and Vit. E in G4 exhibited a significant increase in WG, RBWG and FER. Vit. E neutralized the toxic effect of copper oxychloride and enhanced the growth parameters and feed utilization. Values of all growth and feed utilization parameters (final body weight, weight gain, feed intake, protein efficiency ratio and survival rate (SR) were significantly higher, but FCR was significantly lowest (better) in vitamin E-treated fish (Hassaan et al., 2014). Similarly, Galaz et al. (2010) recorded that the growth performance of fish fed on a diet supplemented with vitamin $\mathrm{E}$ was significantly higher in juvenile parrotfish (Oplegnathus fasciatus), while, lower feed conversion ratio (FCR) was observed.

Furthermore, vitamin E dietary supplementation protected fish against the challenge of pathogenic bacteria. Fish exposed to copper sulfate in G3 obtained the highest post-challenge mortality, lowest survival rate and relative protection. However, fish were highly resistant to Aeromonas hydrophila challenge in G2 fed on a diet supplemented with vitamin $\mathrm{E}$, had the lowest post-challenge mortality, highest survival rate. Challenged fish in G4 showed lower motility and higher survival and than G3 exposed to copper sulfate only. These results agreed with Farhangi and Jafaryan (2019) who recorded a significant increase in the mortality rate of fish exposed to increasing concentrations of copper. On the other hand, Prieto et al. (2008) recorded that the growth and survival of fish were relatively unaffected by heavy metals in a vitamin $\mathrm{E}$ supplemented diet. The addition of Vit. E was necessary to increase survival (Lim et al., 2010).

In the present study, the significant decrease in $\mathrm{PCV}$ and $\mathrm{Hb}$ may be due to the inhibition of erythropoiesis, heme synthesis, osmoregulatory dysfunction, or due to increased rate of erythrocyte destruction in the hematopoietic organ. These results agreed with Hassaan et al. (2014) who found that fish exposed to a sublethal dose of copper oxychloride showed significantly lower values of hematocrit and hemoglobin. However, vitamin $E$ significantly lowered the hematological changes and decreased the toxic effect of the metal and stimulated the immune response to cope with the stress (Hassaan et al., 2014). In the second group, the significant increase in white blood cell counts after copper sulfate exposure and a week postchallenge indicate damage may be due to challenge of body tissues and severe physical stress (Singh et al., 2008). In carp experimentally infected with A. hydrophila, Harikrishnan et al. (2003) had related increased WBC counts, corroborating the present findings.

Metals can increase or decrease the activities of hepatic enzymes and can lead to histopathological hepatic alterations, depending on fish species, the metal type and concentration, length of exposure and other factors. In accordance with the present study, El-Keredy et al. (2017) found that copper exposure increased serum AST, ALT, CAT and SOD enzymes activities. The current study revealed that serum creatinine significantly increased in the copper sulfate-exposed fish. This refers to kidney failure and increased muscular tissue catabolism. This suggests that copper-exposed fish had glomerular dysfunction rather than tubular insufficiency. However, low-level copper sulfate leads to changes in blood chemistry, damages of gills and the liver in fish (Mutlu et al., 2015). On the other hand, Hassaan et al. (2014) observed that vitamin E significantly lowered the biochemical response induced by copper oxychloride. Furthermore, Metwally et al. (2002) reported non-significant changes in serum creatinine of $O$. niloticus fed a diet containing to Vit. E.

Exposure to heavy metals had a detrimental effect on the immunological response in fish. In the current study, copper exposure reduced Nile tilapia fish immune response and increase fish susceptibility to bacterial challenge through the reduction of IgM. In agreement with the present findings, fish exposed to a sub-lethal dose of copper oxychloride showed significantly lower values of immunoglobulin. On the other hand, IgM levels showed an improvement in fish treated with vitamin $\mathrm{E}$ (Hassaan et al., 2014). The serum level of the IgM was significantly increased in the 
resistant fish (infected with no symptoms) than the non-infected and susceptible fish diseased/susceptible (infected with symptoms) (Abdel-Magid et al., 2018). Vitamins E and C increased specific immunity and reduced mortality (Sahoo and Mukherjee, 2002).

The liver is known to be an important organ for coping with oxidative stress, as it has the highest antioxidant enzyme activities to protect them from oxidative stress caused by metals. Antioxidant responses have been suggested as biomarkers of exposure to metals in aquatic organisms (Atli and Canli 2010). The antioxidant system was disturbed by copper exposure and the potentially damaging impacts, with distinct effects in juveniles of Oreochromis niloticus. The exposure to copper may have increased ROS, leading to an increase in the antioxidant enzyme SOD (Boareto et al., 2018). In agreement with the current study, copper sulfate induced induction in antioxidant enzyme activities in fish (Trivedi et al., 2012). Accordingly, CuSO4 significantly increased the CAT and SOD activity levels in the liver, kidney and gill of C. umbla (Kirici et al., 2017) and in tilapia fish (El-Keredy et al., 2017). Superoxide dismutase (SOD) converts superoxide anion radicals to hydrogen peroxide and catalase (CAT) reduces hydrogen peroxide to water (Allocati et al., 2018). The significant differences in the antioxidant responses and capacities of liver tissue could be due to different rates of free radical generation, differences in susceptibility to oxidative damage of the tissues. Glutathione peroxidase catalyzes the reduction of hydrogen peroxide and lipid peroxides and is considered an efficient protective enzyme against lipid peroxidation at the expense of GSH (Yonar et al., 2016). CuSO4. 5H2O caused a significant decrease in the glutathione reductase (GR) activities the all tissues in a dose-dependent manner. Decreased GR activity may lead to GSH depletion if its loss cannot be compensated by the synthesis of new glutathione molecules as observed in the present study (Stara et al., 2012).

In the current study, fish challenged with Aeromonas hydrophila and not treated (G1) exhibited a significant decrease in hepatic antioxidants (GSH, SOD and CAT) in comparison to other tested groups receiving Vit. E and/or CuSO4. Abdel-Magid et al. (2018) concluded that immunosuppression and oxidative stress are two sides of the same coin as each one can induce the other. They suggest a positive link between bacterial challenge and stimulation of oxidative stress in susceptible fish as evidenced by inhibition of antioxidant enzymes (SOD and CAT) activities and GSH content. However, this link was negative in resistant fish. Similar results were reported by Deng et al. (2013) who found a significant decrease in liver SOD and CAT in fish challenged by Aeromonas hydrophila and Fei et al. (2017) who observed that the activity of CAT decreased significantly in infected fish. Change in SOD level following challenge indicates the important role played by this enzyme not only in the removal of excessive ROS but also in immunity. In consistent with our results, Tang et al. (2017) found that the activity of SOD decreased significantly after Aeromonas hydrophila challenge in diseased fish. This suggests a positive link between bacterial challenge and stimulation of oxidative stress in susceptible fish as evidenced by inhibition of antioxidant enzymes (SOD and CAT) activities and GSH content. However, this link was negative in resistant fish. The clinical examination of infected fish revealed the presence of typical clinical signs of $A$. hydrophila challenge, including hemorrhages at the base of pectoral fin with inflammation of anal opening, erosion in pectoral fin and tail fin, and scales desquamation. Moreover, the internal examination of infected fish revealed the presence of severe enteritis with sloughing of internal mucosa and yellow mucous in the intestinal lumen, pale enlarged liver with enlarged gall bladder, congested and inflamed spleen, and ascites in severe cases. Reisolation of the causative bacteria used in our challenge test occurred and this confirms the success of the challenge test in the current study (Noor El Deen et al., 2014).

Also, Senug et al. (2007) recorded that vitamin $\mathrm{E}$ appears to provide protection against oxidative stress caused by $\mathrm{Pb}$ toxicity. Vitamin E functions as a lipid-soluble antioxidant, protecting biological membranes, lipoproteins, 
and lipid stores against oxidation (Lee and Shiau, 2004). The antioxidative functions of vitamin $\mathrm{E}$ include scavenging of free radicals to terminate lipid peroxidation, which can initiate damage to unstable intracellular components including membranes, nucleic acids and enzymes, thereby result in pathological conditions and indirectly result in reduced growth (Paul et al., 2004). Vitamin E ( $\alpha$-tocopherol) as a lipid-soluble vitamin can act as antioxidants by scavenging reactive oxygen species from different tissues of organisms (Agarwal and Goel, 2010).

The histological alternations resulting from the exposure to metals are found to be a compensatory response to keep metal from entering through gill cells. Copper sulfate exposure leads to some of the typical gill lesions. The main alternations observed after the exposure to the cupper were epithelial hyperplasia, lifting of the lamellar epithelium, edema in the filamental epithelium, Curling, clubbed tips of the secondary lamella and finally a complete fusion of several secondary lamellae. Exposure to concentrations of copper sulfate more than $10 \mathrm{mg} / \mathrm{L}$ increased the arithmetic thickness of secondary lamella epithelium in O. niloticus (Alkobaby and Abd El-Wahed, 2017). The detected changes in tilapia gills as gill hyperplasia, edema, lifting of lamellar epithelia, intense lamellar vasodilation and curling of secondary lamellae were generally accentuated to the lethal effect of copper, Figueiredo-Fernandes et al. (2007) demonstrated that gill hyperplasia and interstitial edema are the more frequent lesions observed in the gill epithelium of fish exposed to heavy metals, and with Shaw et al. (2012) concluded that edema may result in osmotic imbalance. The lifting of lamellar epithelium is another histological change observed, probably induced by the incidence of severe edema. A complete fusion of several lamellae was recorded. This could be attributed to the direct effect of heavy metal. Curling and clubbed tips of secondary lamella were occasionally. Increasing epithelial lifting and hyperplasia were depending on the increase of waterborne $\mathrm{Cu}$ concentrations. The fusion of the secondary lamella was also, reported by Ostaszewska et al. (2016) and Jooyandeh et al. (2016). Accordingly, Van Heerden and Tiedt,
(2004) found the increase in the arithmetic thickness of gill epithelium in Oreochromis mossambicus and Tilapia sparrmanii occurred when exposed to copper, respectively. Thickening of the epithelium in gills of fish exposed to copper was caused by hypertrophy in cells, besides lamellar telangiectasis. However, morphometric measurements on gills of fish such as the arithmetic thickness of secondary lamella epithelium could be a simple and real indicator of toxic exposure before permanent damage occurs. Fish exposed to copper oxychloride show several histological alterations, namely hemorrhage in primary lamellae and separation in secondary lamellae. The liver of the non-treated fish exhibits a normal appearance and structure with no pathological abnormalities. The hepatocytes present a homogenous cytoplasm and a large central or subcentral spherical nucleus, except some samples only, showed fatty degeneration. However, fish exposed to copper oxychloride exhibited severe hemorrhage in hepatic tissue (Hassaan et al., 2014).

The liver is considered as the principal organ of detoxification and a good indicator of aquatic environmental pollution (Ahmed, 2012). The liver is the main organ for the metabolism of $\mathrm{Cu}$ in fish and for detoxification and more responsive for damage. Fish exposed to copper sulfate showed cytoplasmic rarefaction and an increase of cytoplasmic vacuolation and nuclear pyknosis (Chen et al., 2012 a, b). These alternations could be explained by $\mathrm{Cu}$-induced oxidative stress in the tissue of the liver (Hoyle et al., 2007). However, the liver of the $\mathrm{Cu}$-treated fish showed histological alternations such as cytoplasmic rarefaction, an increase of cytoplasmic vacuolation, decreasing the number of hepatocytes nucleus in hepatic tissue and nuclear pyknosis (Alkobaby and Abd El-Wahed, 2017). Vacuolar degeneration and disrupted hepatocytes detected in exposed fishes substantiates the potency of copper in causing liver damage. Vacuolar degeneration and focal necrosis in hepatocytes in the present study coincides with similar observations in Etroplus maculatus exposed to lindane (Bijoy et al., 2011). In addition, Farhangi and Jafaryan (2019) observed degenerated tubules 
of their kidney, expansion of Bowman's capsule and hepatocytes necrosis in fish exposed to increasing concentrations of copper. $\mathrm{Cu}$ exposure leading to various pathological changes in the liver (necrosis and mild vacuolation), kidney (tubular vacuolation), spleen (lymphoid depletion), gills (lamella fusion) (El-Keredy et al., 2017). Moreover, chronic copper accumulation in the liver of fish causes hepatocyte lysis, cirrhosis and ultimately death (Osman et al., 2009). Following exposure of fish to toxic agents, histological alterations in the fish were found at the level of the tubular epithelium and glomerulus (Yancheva et al., 2016).

Vitamin E deficiency could cause hepatic necrosis in fish (Idris and Hassan, 2002). Furthermore, fish exposed to copper oxychloride and fed diet supplemented with Vit. E showed a decrease in the appearance of several liver alterations. Also, fish fed a diet supplemented with Vit. E and not treated with copper oxychloride showed no lesions of the liver. These results are in agreement with those of Mahmoud (2009). Histological examination of $\mathrm{O}$. niloticus gills showed a typical structural organization of the lamellae in fish fed on dietary Vit. E and not exposed to copper oxychloride; some samples showed cell degeneration in secondary lamellae (Hassaan et al., 2014).

\section{CONCLUSION}

In conclusion, dietary supplementation of 600 $\mathrm{mg} / \mathrm{kg}$ diet vitamin $\mathrm{E}$ showed positive effects on growth performance of Nile tilapia fish intoxicated with copper sulfate. Vitamin E was effectively used to maintain hemato-biochemical parameters near the normal values. The curative effects of vitamin $\mathrm{E}$ included improvement in hepatorenal functions and pathological lesions. This study indicated that incorporation of vitamin E could help Nile tilapia to resist Aeromonas hydrophila invasion through its immunomodulatory activity as evident from increased immunoglobulin $\mathrm{M}$, antioxidants and fish survival.

\section{REFERENCES}

Abdel-Magid, A.D.; Abd Elrazik, F.S.; Agour, M.G. and El-Magd, M.A. (2018): Nile tilapia resistant to Aeromonas hydrophila challenge had higher serum IgM and antioxidant enzymes activities. Arabian Journal of Medical Sciences (AJMS). 2(1): 9-12 OI:10.5455/ajms.15, http://www.ajms.tk.

Aebi, H. (1984): Catalase in vitro. Methods Enzymology, 105: 121-126.

Abo-Al-Ela, H.G.; El-Nahas, A.F.; Mahmoud, S. and Ibrahim, E.M. (2017): Vitamin C Modulates the Immunotoxic Effect of 17alpha-Methyltestosterone in Nile Tilapia. Biochemistry, 56, 2042- 2050.

Agarwal, R. and Goel, S.K. (2010): Chandra $\mathrm{R}$, Behari JR. Role of vitamin $\mathrm{E}$ in preventing acute mercury toxicity in rat. Environ Toxicol Pharmacol., 29:70-80.

Ahmed, N.A. (2012): Biochemical studies on pollution of the River Nile at different stations of delta barrage (Egypt). Ph.D. thesis. Fac. of Agric. Benha, Univ.

Alkobaby, A.I. and Abd El-Wahed, R.K. (2017): The Acute Toxicity of Copper to Nile Tilapia (Oreochromis niloticus) Fingerlings and its Effects on Gill and Liver Histology. Journal of Aquaculture Research \& DevelopmentJ Aquac Res Development, 8: 465. doi: 10.4172/2155 $-9546.1000465$

Allocati, N.; Masulli, M.; Di Ilio, C. and Federici, L. (2018): Glutathione transferases: substrates, inhibitors and pro-drugs in cancer and neurodegenerative diseases. Oncogenesis, (7): 1-15.

Amend, D.F. (1981): Potency testing of fish vaccines. Fish Biologics: Serodiagnostics and Vaccines, 49, 447454.

AOAC (Association of Official Analytical Chemists) (1990): Official Methods of Analyses. $15^{\text {th }}$ edition (K. Helrich, Ed.). Association of Official Analytical Chemists Inc., Arlington, Virginia.

Atabati, A.; Keykhosravi, A.; Askari-Hesni, M.; Vatandoost, J. and Motamedi, M. (2015): Effects of copper sulfate on gill histopathology of grass carp (Ctenopharyngodon idella). -. Iranian Journal of Ichthyology, 2: 35-42.

Atli, G. and Canli, M. (2010): Response of antioxidant system of freshwater fish Oreochromis niloticus to acute and 
chronic metal $(\mathrm{Cd}, \mathrm{Cu}, \mathrm{Cr}, \mathrm{Zn}, \mathrm{Fe})$ exposures. Ecotoxicological Environment Safety, 73: 1884-1889. https://doi.org/10.1016/j.ecoenv.2010.09 .005 .

Austin, B. and Austin, A.D. (1987): Motile Aeromosnas In Bacterial Fish Pathogens, $1^{\text {st }}$ end pp.171-177. Chichester, UK: Ellis Horwood.

Bancroft, J.D.; Layton, C. and Suvarna, S.K. (2013): Bancroft's Theory and Practice of Histological Techniques. $7^{\text {th }}$ ed., Churchill Livingstone, Elsevier. pp. 151.

Beutler, E.; Duron, O. and Kelly M.B.J. (1963): "Colorimetric method for determination of reduced glutathione (GSH)". Lab Clin. Med. 61, 882.

Bijoy, N.; Nandan, S. and Nimila, P.T. (2011): Lindane toxicity: Histopathological, behavioural and biochemical changes in Etroplusmaculatus. Marine Environ. Res. 30: 1-8.

Blaxhall, P.C. and Daisley, K.W. (1973): Routine haematological methods for use with fish blood. Journal of Fish Biology. $771-781$.

Boareto, A.C.; Giareta, E.P.; Guiloski, I.C.; Rodrigues, M.S.; Freire, C.A. and SilvaDe-Assis, H.C. (2018): Effects of shortterm exposure to copper on biochemical biomarkers in juvenile freshwater fish. Pan-American Journal of Aquatic Sciences (2018), 13(2): 135-147

Chen, W.Y.; Lin, C.J.; Ju, Z.R.; Tsai, J.W. and Liao, C.M. (2012a): Assessing the effects of pulsed waterborne copper toxicity on life-stage tilapia populations. Sci of the Total Environ., 417-418: 129137.

Chen, Q.L.; Luo, Z.; Zheng, J.L.; Li, X.D. and Liu, C.X. $(2012$ b): Protective effects of calcium on copper toxicity in Pelteobagrus fulvidraco: Copper accumulation, enzymatic activities, histology. Ecotoxicol and Environ Saf., 76: 126-134.

El-Keredy, M.S.A.; El-Shenway, A.M.; Diab, A.M.; Ali, G.I.E. and Kotb, W.S. (2017): Effect of dietary vitamin $\mathrm{C}$ and BGlucan to alleviate the toxic effect of copper sulphate in tilapia fish. Alexandria Journal of Veterinary
Sciences (AJVS), 55 (2): 36-49. DOI: 10.5455/ajvs.276295 www.alexjvs.com

Farhangi, M. and Jafaryan, H. (2019): The Comparison of Acute Toxicity (96h) of Copper (CuSO4) in Cyprinus Carpio and Rutilus Rutilus. Environment and Pollution; 8 (2); 21-30.

Fei, L.; Yushuang, L.; Pinhong, Y.; Wenbin, W.; Jigang, J.; $\mathrm{Na}, \mathrm{Li}$. and Qing, $\mathrm{H}$. (2017): The effect of Aeromonas hydrophila challenge on the non-specific immunity of blunt snout bream (Megalobramaamblycephala), $\quad 42(3)$ : 239-243.

Figueiredo-Fernandes, A.; Ferreira-Cardoso, J.V.; Garcia-Santos, S.; Monteiro, S.M. and Carrola, J. (2007): Histopathological changes in liver and gill epithelium of Nile tilapia, Oreochromis niloticus, exposed to waterborne copper. Pesquisa Veterinária Brasileira 27(3): 103-109.

Gharedaashi, E.; Nekoubin, H.; Imanpoor, M.R. and Taghizadeh, V. (2013): Effect of copper sulfate on the survival and growth performance of Caspian Sea kutum, Rutilus frisii kutum. Springer Plus, 2:498-503. https://doi.org/10.1186 12193-1801-2-498

Galaz, G.B.; Kim, S.S. and Lee, K.J. (2010): Effects of different dietary vitamin $\mathrm{E}$ levels on growth performance, nonspecific immune responses, and disease resistance against Vibrio anguillarum in Parrot fish, Oplegnathus fasciatus. Asian Aust J Anim Sci., 23(7): 916-923

Gammanpila, M.; Yakupitiy Age, A. and Bart, A.N. (2007): Evaluation of the effects of dietary vitamin $\mathrm{C}, \mathrm{E}$ and Zinc supplementation on reproductive performance of Nile tilapia (Oreochromis niloticus). Sri Lanka J. Aquat. Sci., 12:39-60

Gao, R.; Yuan, Z.; Zhao, Z. and Gao, X. (1998): Mechanism of pyrogallol autoxidation and determination of superoxide dismutase enzyme activity. Bioelectrochemestry Bioenergy, 45: 4145. https://doi.org/10.1016/S0302-4598 (98)00072-5.

Harikrishnan, R.; Nisha Rani, $M$. and Balasundaram, $\quad$ C. (2003): Hematological and biochemical 
parameters in common carp, Cyprinus carpio, following herbaltreatment for Aeromonas hydrophila infection. Aquaculture, 221(1-4): 41-50.

Hassaan, M.S.; Goda, A.M.A.S.; Mahmoud, S.A. and Tayel, S.I. (2014): Protective effect of dietary vitamin $\mathrm{E}$ against fungicide copperoxychloride stress on Nile tilapia, Oreochromis niloticus (L.) fingerlings. Int Aquat Res (2014) 6:58 DOI 10.1007/s40071-014-0058-6

Hathcock, J.N.; Azzi, A.; Blumberg, J.; Brat, T.; Dickinson, A.; Frei, B.; Jialal, I.; Johnston, C.S.; Kelly, F.; Kraemer, K.; Packer, L.; Parthasarathy, S.; Sies, H. and Traber, M.G. (2005): Vitamins E and $\mathrm{C}$ are safe across a broad range of intakes. Amer. J. Clin. Nutr., 81(4): 736 -745 .

Henry, R.J. (1974): Clinical chemistry principles and techniques, $2^{\text {nd }}$ ed. Harper and Row Publ, New York 525

Hoyle, I.; Shaw, B.J. and Handy, R.D. (2007): Dietary copper exposure in the African walking catfish, Clarias gariepinus: transient osmoregulatory disturbances and oxidative stress. Aquat Toxicol 83: 62-72.

Hrubec, T.C. and Smith, S.A. (2010): Hematology of fishes. Pp. 994-1003. In: Weiss, D. J \& K. J. Wardrop (Eds.). Schalm's veterinary hematology. 6th ed. Ames, Iowa, Wiley-Blackwell.

Idris, A. and Hassan, A.A. (2002):A review of medical biochemistry. Bioch. Dept., Fac. Med., Zagazig, Univ 1-263

Jiraungkoorskul, W.; Sahaphong, S. and Kangwanrangasan, N. (2007): Toxicity of copper in butterfish (Poronotus triacanthus): tissues accumulation and ultrastructural changes. Environ Toxicol., 22: 92-100. doi:10.1002/ tox. 2023

Jooyandeh, F.; Sadeghpour, A.; Khara, H. and Pajand, Z. (2016): Histopathological and bacterial study of skin and gill of grass carp, Ceteopharyngodon idella, (Valenciennes 1844) exposed to copper sulfate and potassium permanganate. $\mathbf{J}$ Parasite Dis 40: 1009-1013.

Deng, J.; Kang, B.; Tao, L.; Rong, H. and Zhang, $X$. (2013): Effects of dietary cholesterol on antioxidant capacity, non- specific immune response, and resistance to Aeromonas hydrophila in rainbow trout (Oncorhynchus mykiss) fed soybean meal-based diets. Fish \& Shellfish Immunology, 34(1):324-331

Kirici, M.; Turk, C.; Caglayan, C. and Kirici, M. (2017): Toxic effects of copper sulphate pentahydrate on antioxidant enzyme activities and lipid peroxidation of freshwater fish capoeta Umbla (Heckel, 1843) tissues. Applied Ecology and Environmental Research, 15(3): 1685-1696.

Kwok, C.K.; Yang, S.M.; Mak, N.K.; Wong, C.K.; Liang, Y.; Leung, S.Y.; Young, L. and Wong, M.H. (2010): Ecotoxicological study on sediments of Mai Po marshes, Hong Kong using organisms and biomarkers. Ecotoxicological Environment Safety, 73: 541-549. https://doi.org/10.1016/ j.ecoenv.2010.01.012.

Lasiene, K.; Straukas, D.; Vitkus, A. and Juodziukyniene, N. (2016): The influence of copper sulphate pentahydrate $(\mathrm{CuSO} 4.5 \mathrm{H} 2 \mathrm{O})$ on the embryo development in the guppies (Poecilia reticulata). Italian Journal of Animal Science 15: 529-535.

Lee, M.H. and Shiau, S.Y. (2004): Vitamin E requirements of juvenile grass shrimp, Penaeus monodon, and effects on nonspecific immune responses. Fish Shellfish Immunol., 16: 475-485.

Lim, C.; Yildirim-Aksoy, M.; Welker, T. and Klesius, P.H. (2010): Growth Performance, Immune response, and resistance to Streptococcus iniae of Nile Tilapia, Oreochromis niloticus, fed diets containing various levels of vitamins $\mathrm{C}$ and E. Journal of The world Aquaculture Society, 41(1).

Lushchak, V.I. (2011): Environmentally induced oxidative stress in aquatic animals. Aquatic Toxicology., 101: 1330. doi:10.1016/j.aquatox.2010.10.006.

Mahmoud, S.A. (2009): Effect of different artificial diets on the growth rate condition and histological structure of Nile tilapia (Oreochromis niloticus). J Fish Hydrobiol., 4(1):29-34

Mal, T.K.; Adorjan, P. and Corbett, A.L. (2002): Effect of copper on growth of an 
aquatic macrophyte, Elodea canadensis. Environ Pollut. 120: 307-311.

Metwally, M.A.A.; Ali, M.A.; El-Sayed, A.M.S. and Salah, M.E. (2002): Biochemical effect of different concentrations of vitamin $\mathrm{E}$ and selenium on copper toxicity in tilapia (Oreochromis niloticus). In: The 1st scientific conference on Aquaculture organized by the Egyptian aquaculture society and Uni. of Suez Canal 13-15 December, 2002 El-Arish 13-15 Dec., pp 401-409

Moniruzzaman, M.; Lee, J.; Lee, J.; Won, S.; Damusaru, J.H. and Bai, S.C. (2017): Interactive effect of dietary vitamin $\mathrm{E}$ and inorganic mercury on growth performance and bioaccumulation of mercury in juvenile olive flounder, Paralichthys olivaceus treated with mercuric chloride. Animal Nutrition, 3: 276-283.

Mutlu, E.; Aydın, S. and Kutlu, B. (2015): Alterations of Growth Performance and Blood Chemistry In Nile Tilapia (Oreochromis Nuoticus) Affected by Copper Sulfate In Long-Term Exposure. Turkish Journal of Fisheries and Aquatic Sciences. Turk. J. Fish. Aquat. Sci. 15: 487-493.www.trjfas.org ISSN 13032712 DOI: $10.4194 / 1303-2712-$ v15_2_35

Nawaz, M.; Manzl, C. and Krumschnabel, G. (2005): In vitro toxicity of copper, cadmium, and chromium to isolated hepatocytes from carp, Cyprinus carpio L. Bull Environ Contam Toxicol., 75: 652-661.

Noor El Deen, A.E.; Dorgham, S.M.; Hassan, A.H.M. and Hakim, A.S. (2014): Studies on Aeromonas hydrophila in Cultured Oreochromis niloticus at Kafr El Sheikh Governorate, Egypt with Reference to Histopathological Alterations in Some Vital Organs. World J. Fish \& Marine Sci., 6 (3): 233-240.

NRC (1993): Nutrient Requirements of Fish. National Research Council National Academy Press, Washington, DC, USA.

Osman, M.M.; El-Fiky, S.A.; Soheir, Y.M. and Abur, A.T. (2009): Impact of water pollution on histopathological and electrophoretic characters of
Oreochromis niloticus fish. Res J Environ Toxicol., 3(1): 9-23

Ostaszewska, T.; Chojnacki, M.; Kamaszewski, M. and SawoszChwalibóg, E. (2016): Histopathological effects of silver and copper nanoparticles on the epidermis, gills, and liver of Siberian sturgeon. Environ Sci Pollut Res., 23: 1621-1633.

Paul, B.N.; Sarkar, S. and Mohanty, S.N. (2004): Dietary vitamin E requirement of mrigal, Cirrhinus mrigala fry Aquaculture 242: 529-536.

Prieto, A.I.; Jos, A.; Pichardo, S.; Morento, I. and Camean, A.M. (2008): Protective role of vitamin $\mathrm{E}$ on the microcystininduced oxidative stress in tilapia fish (Oreochromis niloticus). J. Environ. Toxicol Chem., 27(5): 1152-1159.

Puangkaew, J.; Kiron, V.; Somamoto, T.; Okamoto, N.; Satoh, S.; Takeuchi, T. and Watanabe, T. (2004): Nonspecific immune response of rainbow trout (Onchorhynchus mykiss, Walbaum) in relation to different status of vitamin $\mathrm{E}$ and highly unsaturated fatty acids. Fish Shellfish Immun., 16: 25-39.

Rajamanickam, V. (2008): Effect of heavy metals on the level of vitamin E, total lipid and glycogen reserves in the liver of common carp (Cyprinus carpio L.). Maejo International Journal of Science and Technology, (2):391-399.

Rakus, K.L.; Wiegertjes, G.F.; Adamek, M.; Bekh, V.; Stet, R.J. and Irnazarow, I. (2008): Application of PCR-RF-SSCP to study major histocompatibility class II B polymorphism in common carp (Cyprinus carpio L.). Fish Shellfish Immunol 24, 734-744.

Sahoo, P.K. and Mukherjee, S.C. (2002): The effect of dietary immunomodulation upon Edwardsiella tarda vaccination in healthy and immunocompromised Indian major carp (Labeo rohita). Fish Shellfish Immunol., 12:1-16.

Sahoo, D.; Rukmini, M. and Ray, R. (2014): Quantitative analysis of serum levels of alanine and aspartate aminotransferases, $\gamma$-Glutamyl transferase and alkaline phospatase as predictor of liver diseases. Am Inter $\mathbf{J}$ Res in Form, Appl and Nat. Scie., 9: 51-55. 
Schäperclaus, W. (1992): Fish diseases, Vol. 1 (p. 1). Boca Raton, FL: CRC Press.

Schjolden, J.; Sorenson, G.; Nilsson, E. and Poleo, A.B.S. (2007): Toxicity of the copper to Crucian carp (Carassius carassius) in soft water, Sci. Total Environment, 384, 239-251. doi: 10.1016/j.scitotenv.2007.06.009

Senug, H.; Min-Won, B.; Hui-Young, L.; Dong-Jae, K.; Yi-Rang, N.; Kyoung, N.; Song, P.; Hyan, K.; Byoung, H.; Dong, R. and Jae-Hak, P. (2007): Arseniteinduced apoptosis is prevented by antioxidants in zebra fish liver cell line. Toxicol In Vitro, 21(5):870-877.

Sharaf-Eldeen, $K$. and Abdel-Hamid, $N$. (2002): Sublethal effects of copper sulfate, malathion and paraquat on protein pattern of Oreochromis niloticus. Eypt J. Aquat BioL \& Fish., 6(2):167182.

Shaw, B.J.; Al-Bairuty, G.A. and Handy, R.D. (2012): Effects of waterborne copper nanoparticles and copper sulphate on rainbow trout, (Oncorhynchus mykiss): physiology and accumulation. Aquat Toxicol., 116-117: 90-101.

Singh, D.; Nath, K.; Trivedi, S.P. and Sharma, Y.K. (2008): Impact of copper on haematological profile of freshwater fish, Channa punctatus. J. Environ. Biol., 29(2), 253-257

Siwicki, A.K.; Anderson D.P. and Waluga, J. (1993): Nonspecific defense mechanisms assay in fish. II. Potential killing activity of neutrophils and macrophages, lysozyme activity in serum and organs and total immunoglobulin level in serum. Fish Disease Diagnosis and Prevention Methods, Olzsztyn, Poland, pp: 105112. In: Siwicki, A.K., Anderson, D.P. and Waluga, J., Eds., Disease Diagnosis and Prevention Methods, FAO-Project GCP/INT/526/JPN, IFI, Olsztyn, 105111.

SPSS 14 (2006): Statistical package for social science, SPSS for Windows release 14.00, 12 June, 2006 Saunders version, copyright SPSS Inc., 1989 - 2006, All Rights Reserved, copyright.

Stara, A.; Machova, J. and Velisek, J. (2012): Effect of chronic exposure to simazine on oxidative stress and antioxidant response in common carp (Cyprinus carpio L.). Environmental Toxicology and Pharmacology., 33: 334-343.

Tang, Y.; Lu, F.; Luo, Y.; Yang, P.; Wang, W.; Jiang, J.; Li, N. and Han, Q. (2017): The effect of Aeromonas hydrophila challenge on the non-specific immunity of blunt snout bream. Megalobramaamblycephala, 42(3): 239243.

Thrall, M.A. (2004): Veterinary hematology and clinical chemistry. Williams and Wilkins, Philadelphia, pp 277-289.

Trivedi, M.H.; Sangai, N.P. and Renuka, A. (2012): Assessment of toxicity of copper sulphate pentahydrate on oxidative stress indicators on liver of gold fish (Carassius auratus). Bulletin of Environment Pharmacology and Life Sciences, 1: 52-57.

Van Heerden, D.L.R. and Tiedt, A.V. (2004): Gill damage in Oreochromis mossambicus and Tilapia Sparrmanii after short-term copper exposure. International Congress Series, 1275: 195-200.

Wang, T.; Long, X.; Cheng, Y.; Liu, Z. and Yan, S. (2014): The potential toxicity of copper nanoparticles and copper sulphate on juvenile Epinephelus coioides. Aquatic Toxicology, 152: 96104. https://doi.org/10.1016/j.aquatox. 2014.03.023.

Yancheva, V.; Velcheva, I.; Stoyanova, S. and Georgieva, E. (2016): Histological biomarkers in fish as a tool in ecological risk assessment and monitoring programs: a review. - Applied Ecology and Environmental Research, 14: 47-75

Yonar, M.E.; Ispir, U.; Yonar S.M. and Kirici, M. (2016): Effect of copper sulphate on the antioxidant parameters in the rainbow trout fry, Oncorhynchus mykiss. - Cellular and Molecular Biology, 62: 55-58. 


\section{الاورالوقائى لفيتامين E المضاد للأكسدة الناتجة عن تعرض أسماك البلطى لكبريتات النحاس}

\section{هبة أحد طلبة' ، إيمان إسماعيل محمد إسماعيل' ، سلوى أنبيس مهلى عيد" ،

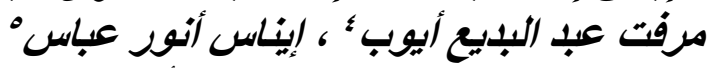

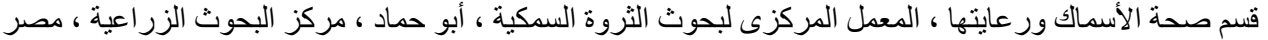

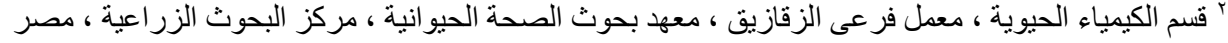

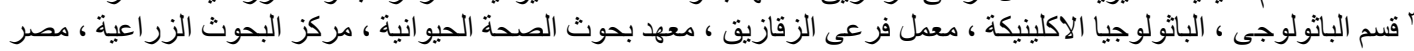

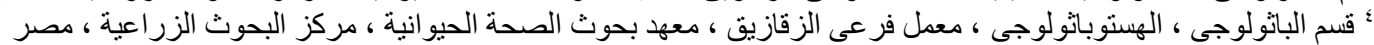

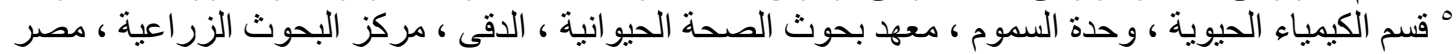

E-mail: abbasenas@gmail.com Assiut University web-site: www.aun.edu.eg

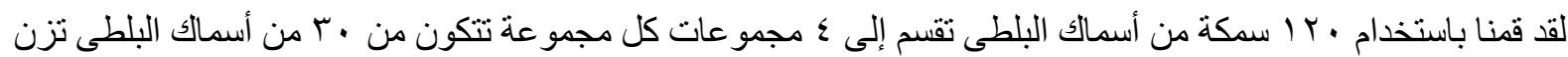

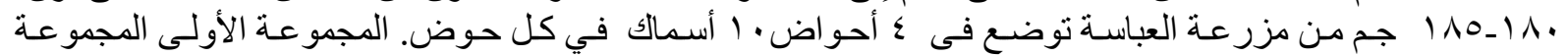

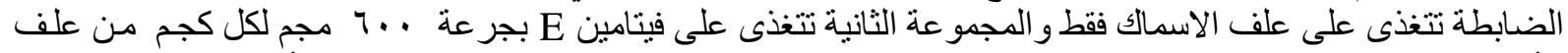

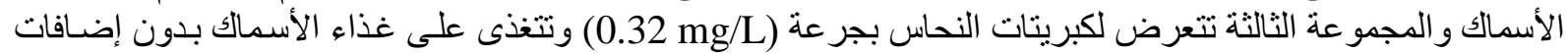

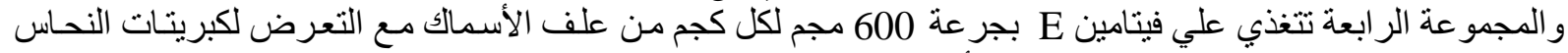

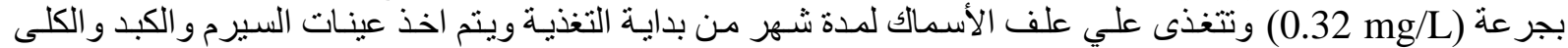

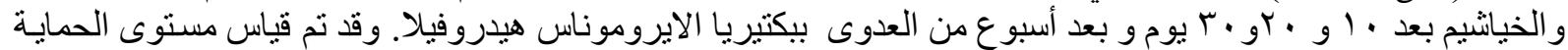

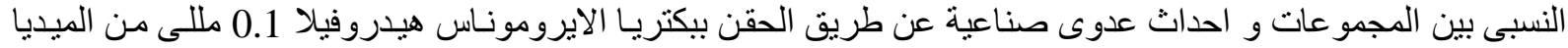

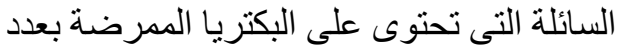
. $\left(5 \times 10^{5} \mathrm{CFU} / \mathrm{ml}\right)$

وقد تبين حدوث نقص ملحوظ فى الوزن و الوزن النسبى وكفاءة الغذاء فى الأسماك المعرضة لكبريتات النحاس.

و كانت نتيجة النفوق أعلى فى المجمو عة المعرضه لكبريتات النحاس فقط ـ ولقد لاحظنا نقص ملحوظ في في عدد كر ات ات الدام

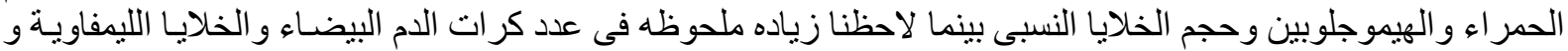

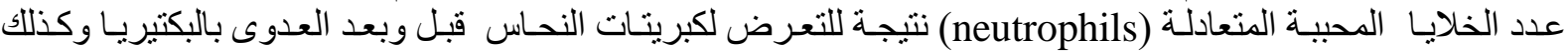

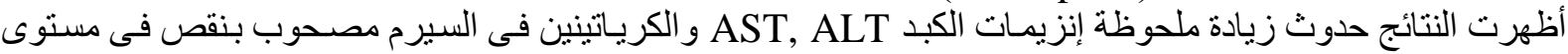

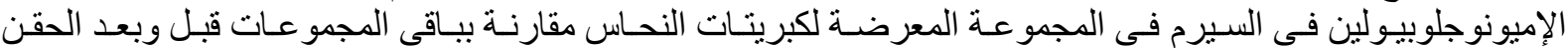

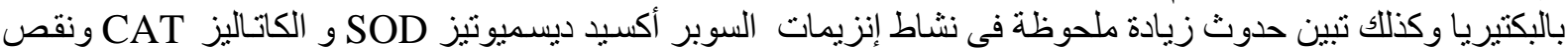

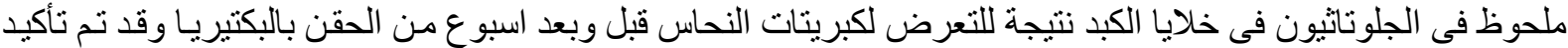

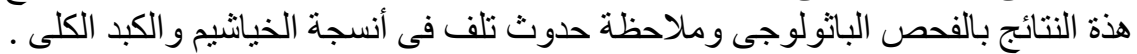

بينما كان الوزن و الوزن النسبى وكفاءة الغذاء أعلى مايمكن فى المجموعة التى تغذى على العلف المضاف إليه فيتامين 600 E

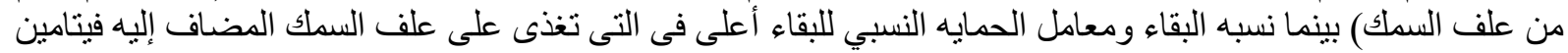

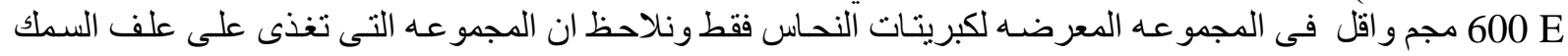

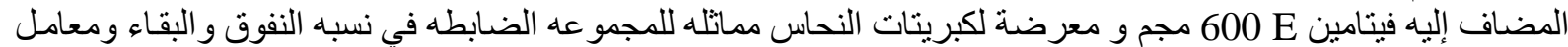

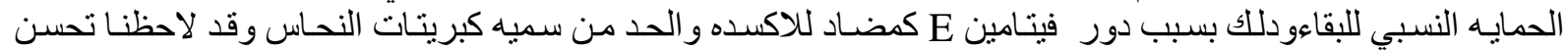

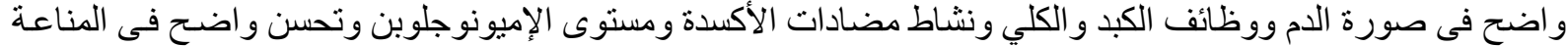

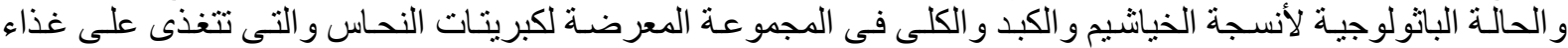

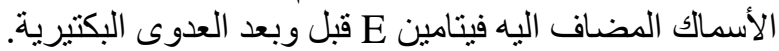

و أخير ا هذه الدر اسة تدعم اضافة فيتامين E لغذاء الأسماك كمحفز ات للنمو و المناعة وكمضساد للاكسده و الحد من سميه كبريتات النحاس. 